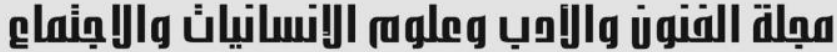

Journal of Arts, Literature, Humanities and Social Sciences www.jalhss.com

\section{الأدوات النحوية في مغني اللبيب عن كتب الأعاريب لالابن هشام "ت761 هـ" بين التركيب والإفراد}

م.د. عباس إبرا اهيم حمد إند البحوث والدراسات ـ المديرية العامة لتربية ديالى ـ ـ وزارة التربية ـ العراق البريد الاكتروني: abbasabrahem446@gmail.com

الملخص

هذا بحث عُنـيَّ بـالأدو ات النحويـة من حيثُ كونها مركبةًُ أو مفردةً، واخترتُ كتابَ "مغنسي اللبيب عن كتب الأعاريب" لابن هشـام الأنصـاري أنموذجاً، لاطـلاع القـارئ الكريم على آراء هذا النحويِّ، فقمتُ بجمـع هذه الأدوات من كتابه ورتَّتُها بحسب عدد حروفها، فبدأت بالثنائيسة و انتهيتُ بالخماسية، ملتزماً الترتيب الهجائي للحروف. وقد اثتنمل البحثُ على مقدمةٍ وتمهيدٍ و أربعةِ أبوابٍ. أمّا التمهيدُ فقد أوجزتُ فيها القول عن "حياة ابن هشـام وأثناره" و " مفهوم الأداة في المصطلح النحوي " و أمّا

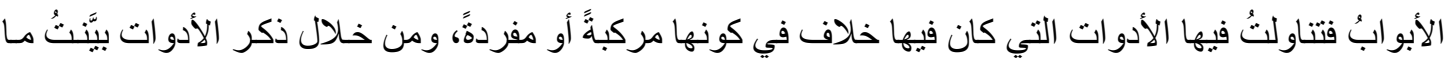

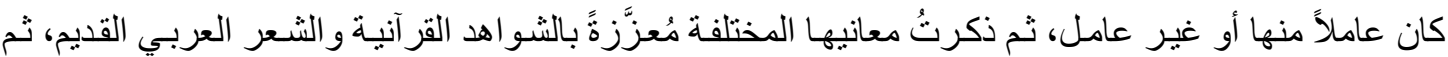
أوردتُ فيها الخلاف كونها مركبةً أو منفردةً، معتمداً رأيَّ ابن هشام أو غيره من النحوبين ممن سبقوه أو جـاءَوا بعده من القدماءٍ و الدحدثين، ثم أوردتُ رأياً في هذه المسائل مو افقاً أو مخالفاً، وأحياناً قد التزمتً الحياد في تركيب أو بساطة بعض الأدوات، وقد توصلتُ من خلال البحث إلى بعض النتائج قد ذكرتُها في الخاتمة.

الكلمات المفتاحية: الأدو ات النحوية، مغني اللبيب عن كتب الأعاريب، أبن هشام. 


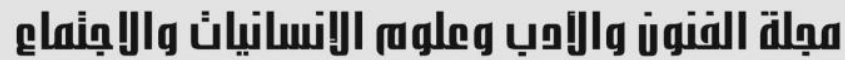 \\ Journal of Arts, Literature, Humanities and Social Sciences \\ www.jalhss.com \\ Volume (64) February 2021 \\ العدد (64) فبراير 2021
}

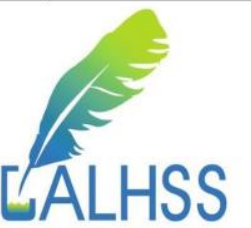

\section{Grammatical Tools in Labeeb Maghna for Alaarab Books to Ibn Hisham (D. $761 \mathrm{AH})$ on Structuring and singling}

\author{
Lect .Dr Abbas Ibrahim Hamad \\ Research and studies - General Directorate of Diyala Education \\ Ministry of Education - Iraq \\ Email: abbasabrahem446@gmail.com
}

\begin{abstract}
This research dealt with the grammatical tools in terms of being compound or single. I chose the book " Labee singer for Alaarab books " by Ibn Hisham Al Ansari, as a model, to inform the reader about the views of this grammarian, so I collect these tools from his book and arranged according to the number of letters. I started with dualism and finished fivefold, committed to the alphabetical order of the letters.

The research included the introduction and preamble and four doors. The introduction has outlined the "life and traces of Ibn Hisham". The doors dealt with the tools that were subject to dispute of being compound or single. Through mentioning the instruments, I showed what are activate or non and stated the various meanings enhanced by Quranic evidences and old Arabic poetry then I mentioned the dispute of being compound or single, depending on the opinion of Ibn Hisham or other grammarians who preceded him or came after him from the ancient modernists. As well as, I stated my opinion on such matters whether agree or not, sometimes I was neutrality about the structure or the simplicity of some tools. I reached through research to some results which I already mentioned in the conclusion.
\end{abstract}

Keywords: grammatical tools, Mughni al-Labib on books of Arabic poems, Ibn Hisham. 


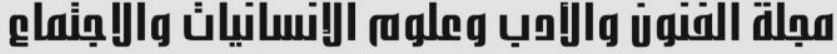

Journal of Arts, Literature, Humanities and Social Sciences www.jalhss.com

الحمد لله وحده، والصلاةُ والسلام على مَنْ لا نبيَ بعده، و على آله الكر ام، و أصحابه العظام وسلّم تسليماً كثيراً.

المقدمة

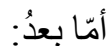

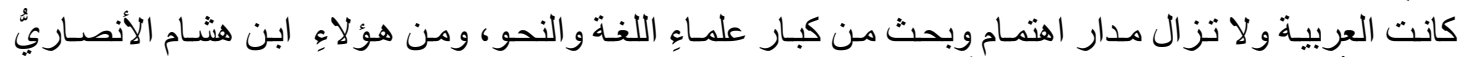

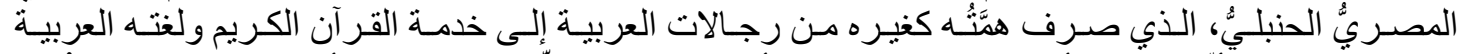

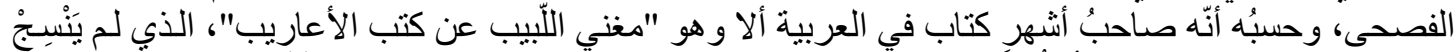

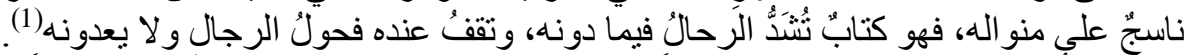

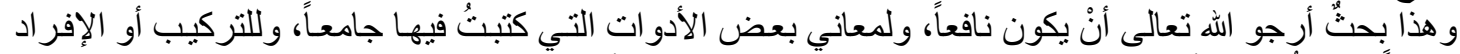

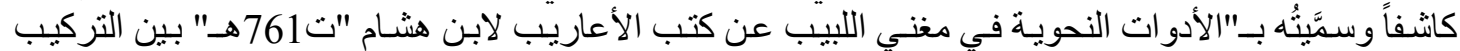

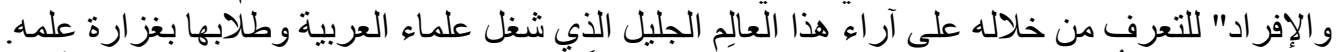

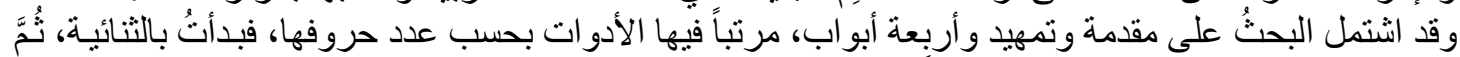

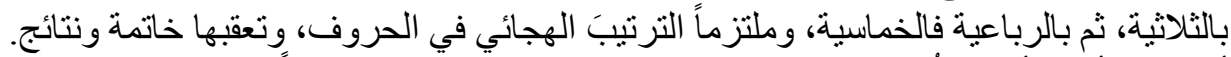

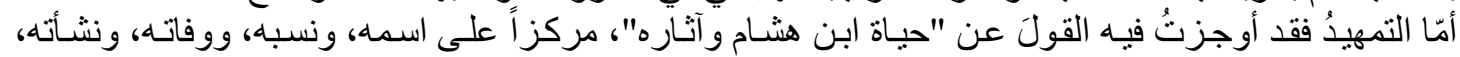

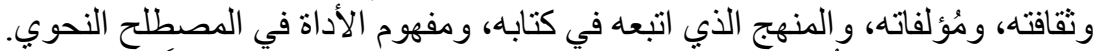

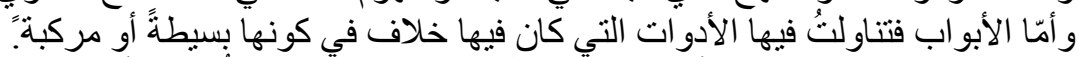

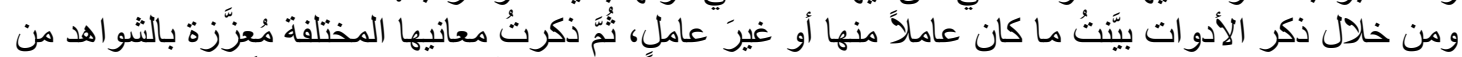

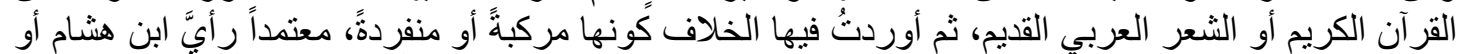

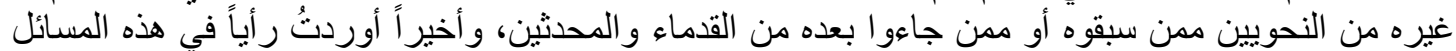

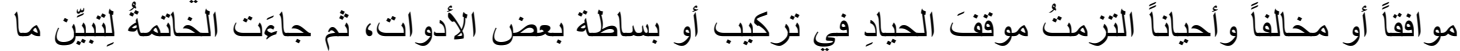
خرج به البحث من نتائج.

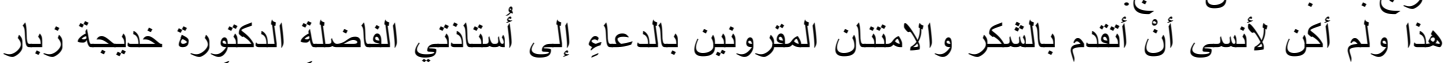

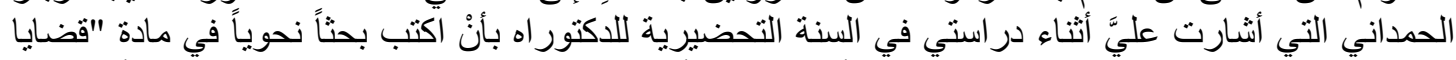

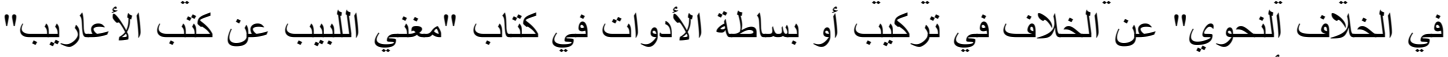

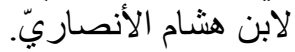

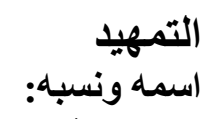

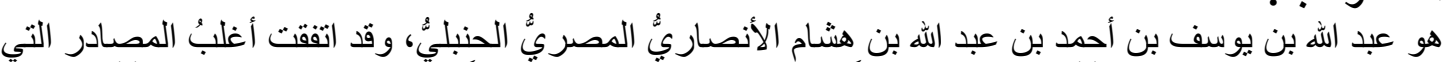

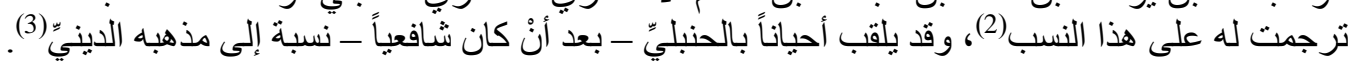
كنيته: اتفقت المصادر التي ترجمت لابن هشام أنّه كان يكنّى بـ" أبي محمد "(4).

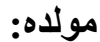
ذكرت المصادرُ أنّ ابن هشام قد ولِد بالقاهرة في شهر ذي القعدة سنة ثمان وسبعمائة(5). نشأته وثثقافته:

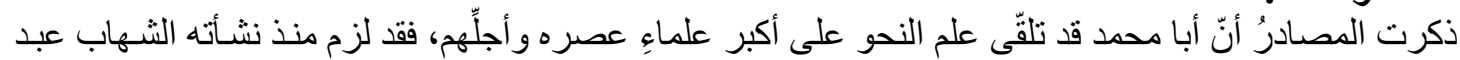

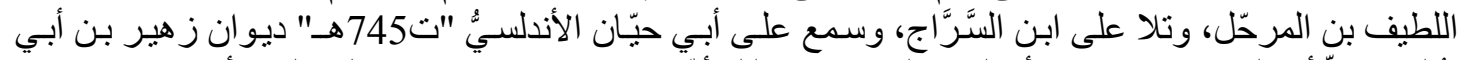

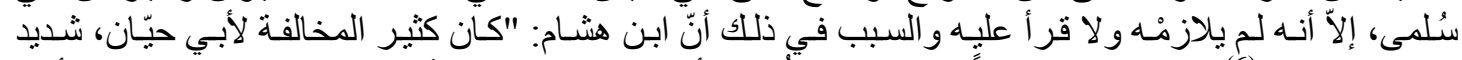

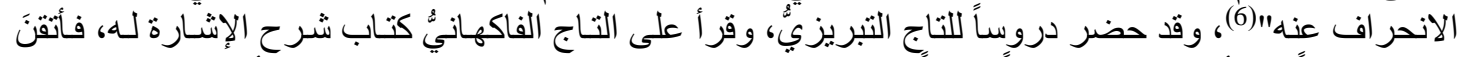

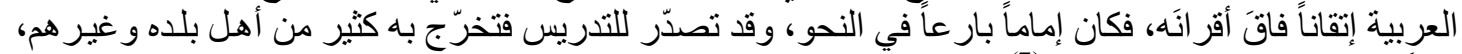

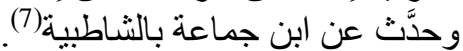

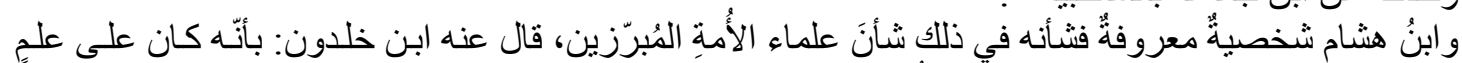

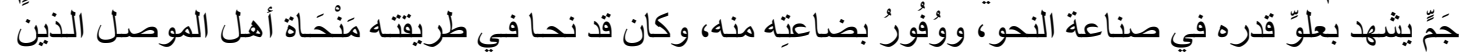

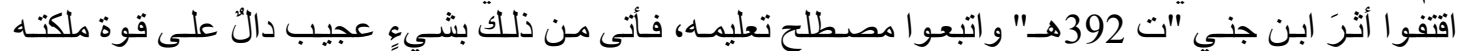




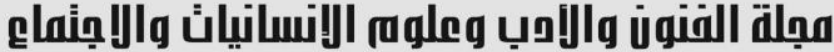

Journal of Arts, Literature, Humanities and Social Sciences www.jalhss.com

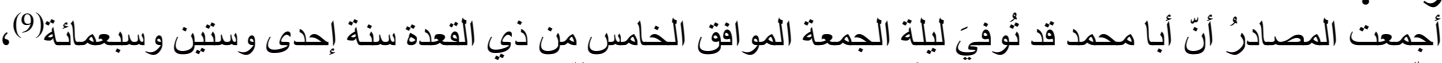
إلاّ صاحب "كثثف الظنون" فقد ذكر في أكثر من موضع من كتابه أنّه مات سنة الثنتين وستين وسبعمائة للهجرة.

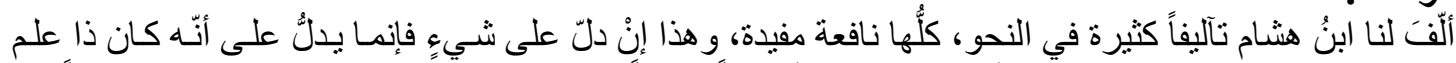

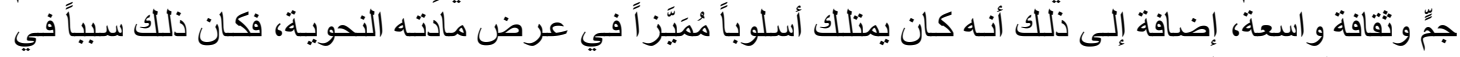
انتشار مُؤلفاته بشكل و اسع، واسعة وهاكها:

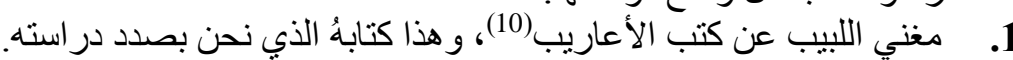

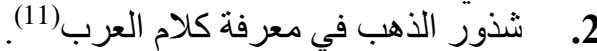

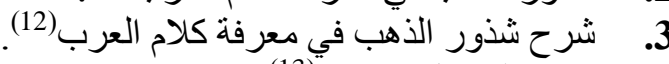
4. 5.

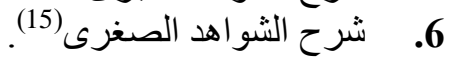
7. 8. 9. 10 11

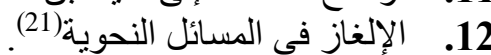

13.

14. التحصيل و التفصيل لكتاب التذييل و التكميل، يقع في عدة مجلدات(23). 15 . 15 الجامع الصغير في النحو (24). 16. 15 الجامع الكبير (25).

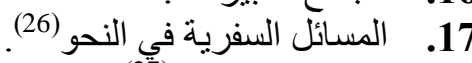
18 القو اعد الكبرى (28).

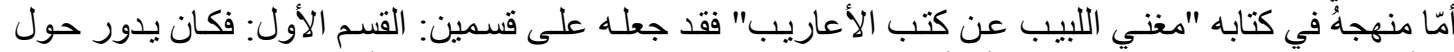

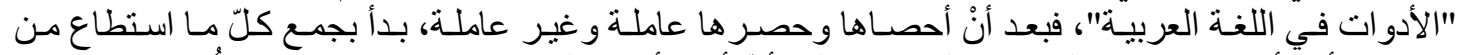

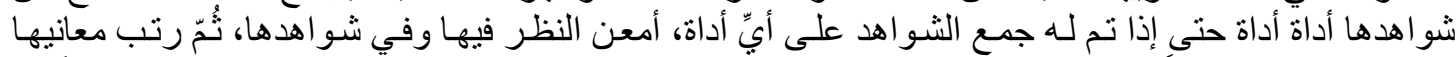

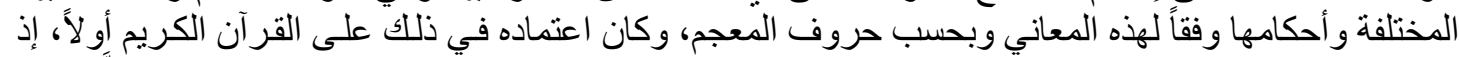

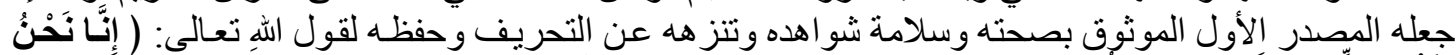

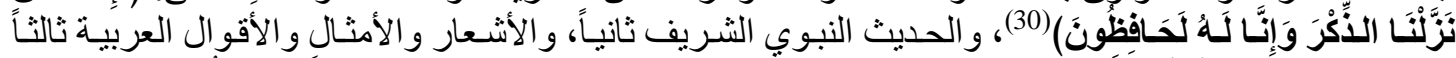

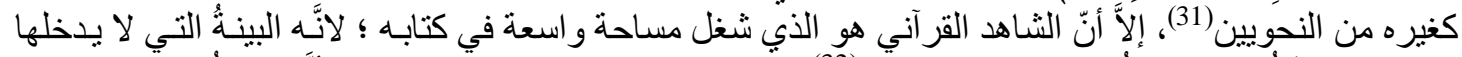

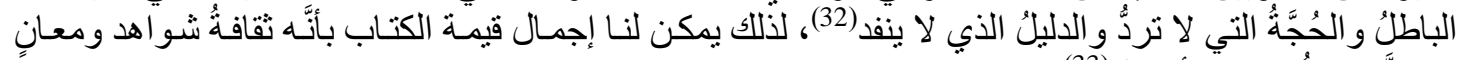

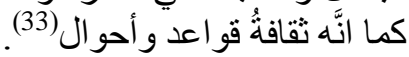

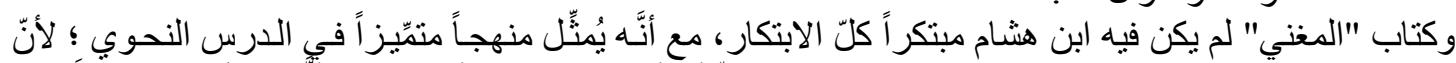

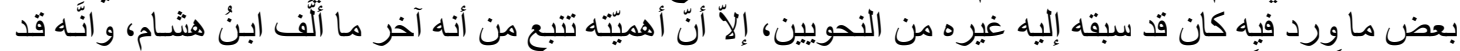

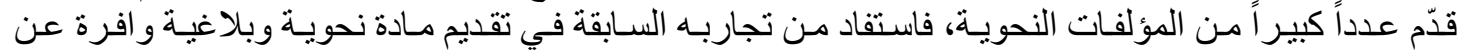

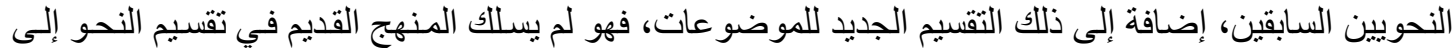

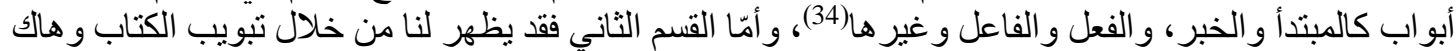




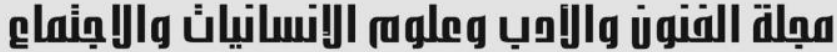

Journal of Arts, Literature, Humanities and Social Sciences
www.jalhss.com

البابُ الأول: في تفسير المفردات "حروفاً و أفعالاً و اسماءًا".

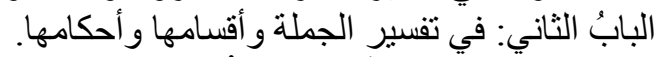

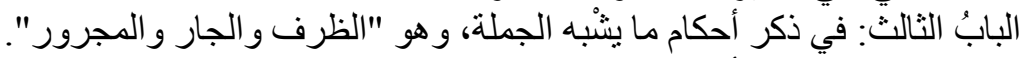

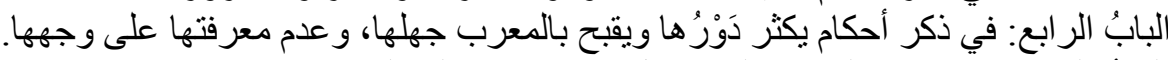

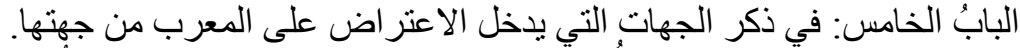

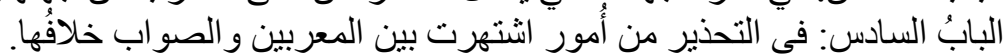

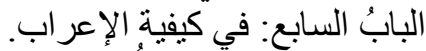

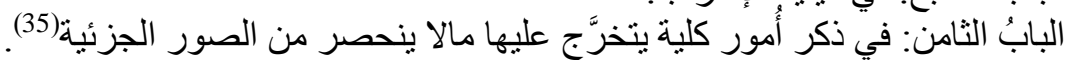

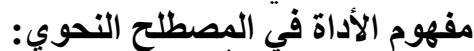

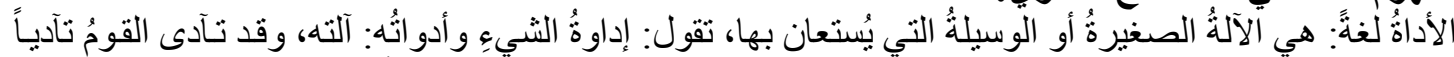

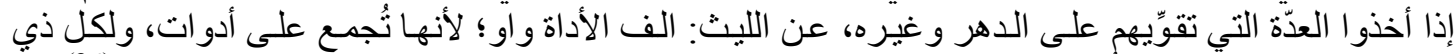

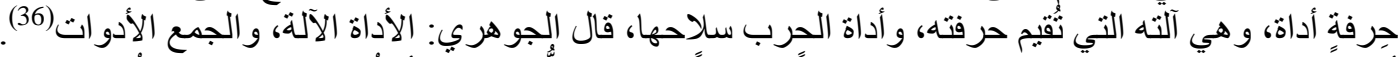

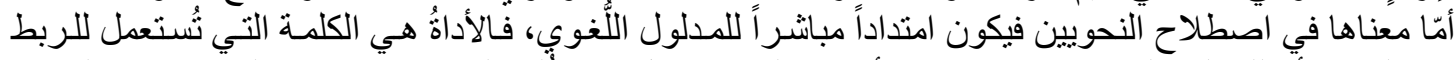

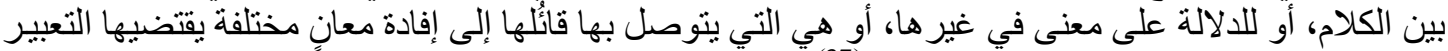

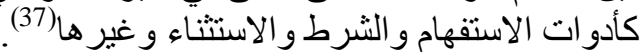

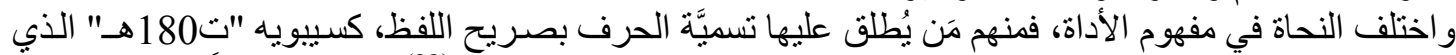

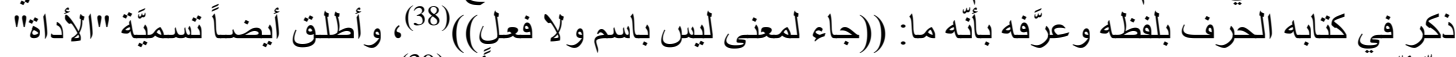

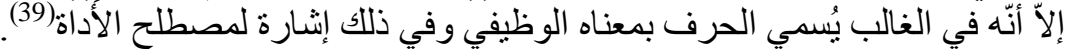

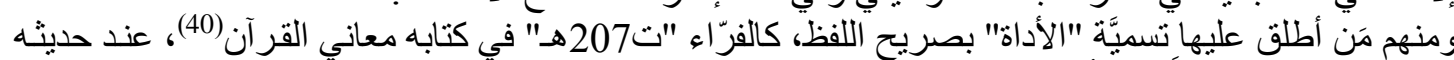

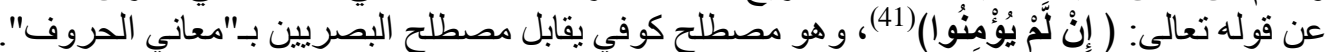

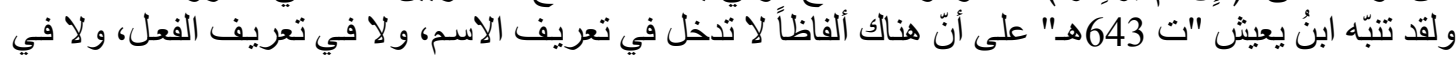

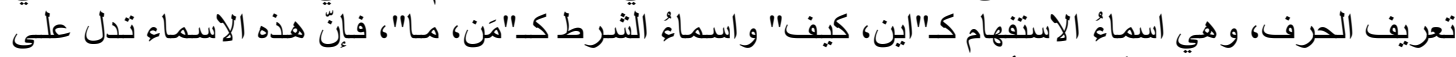

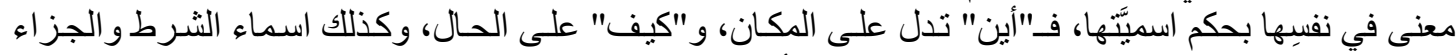

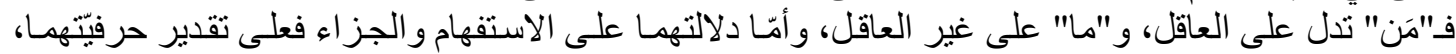

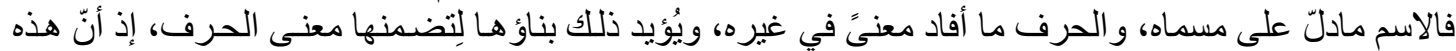

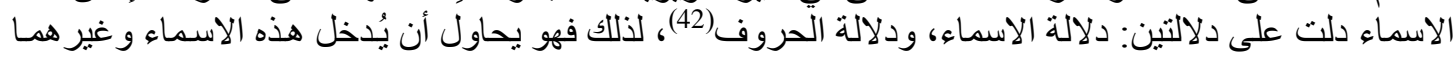

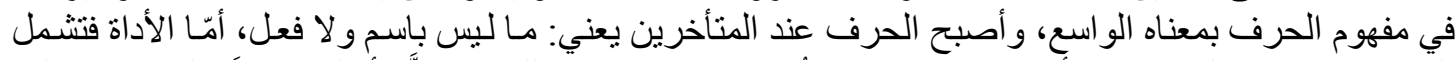

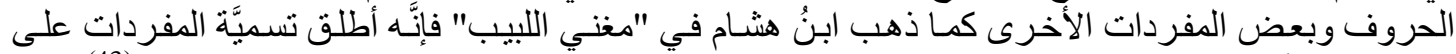

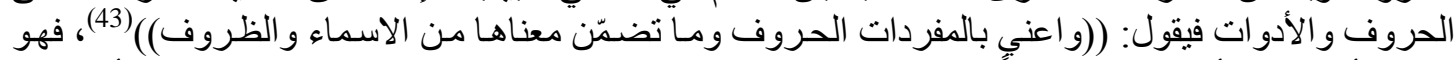

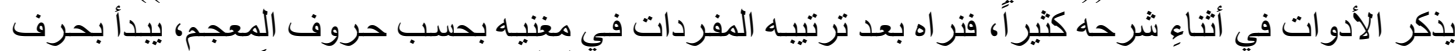

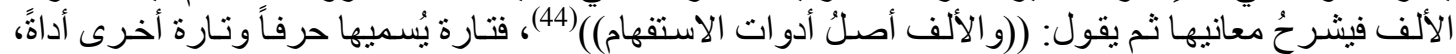

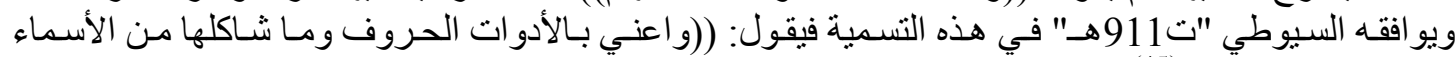

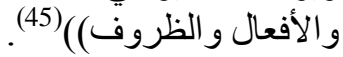

\section{الباب الأول \\ الأدوات الثنائية}

همي كنايةٌ عن العدد المبهر، و لابد لها من تميز يحدد دلالتها، و هي في الكلام نو عان: استفهامية وخبرية.

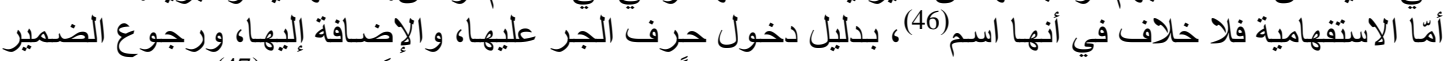

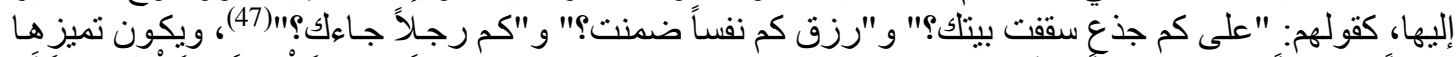

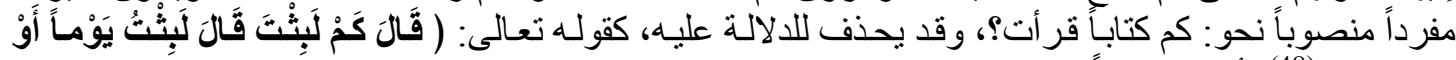

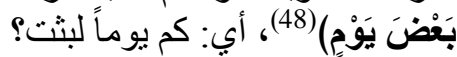

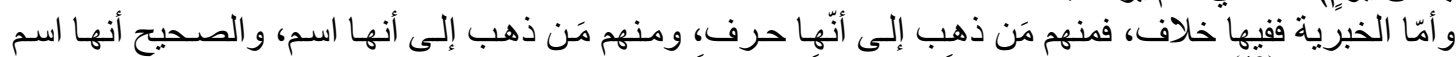

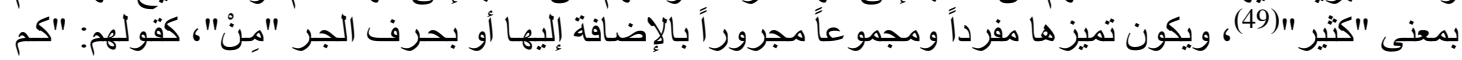




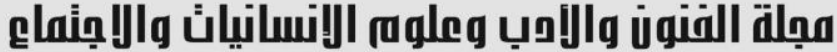

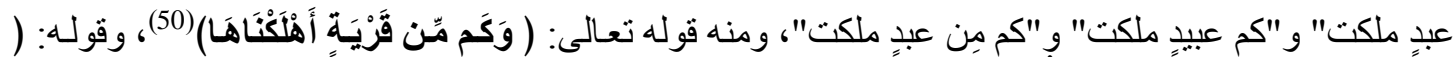

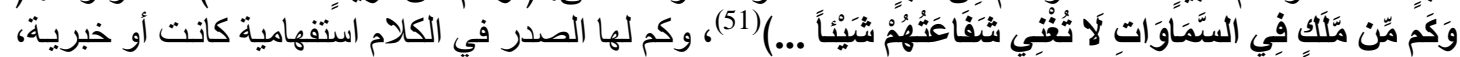

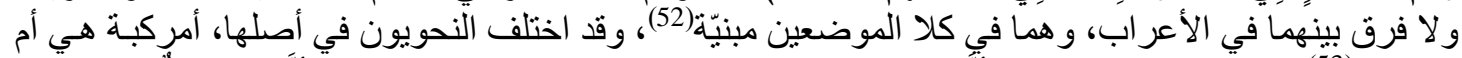

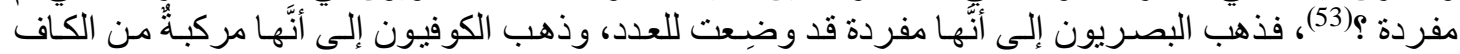
و "ما"، ثم حذفت الألف لكثرة الاستعمال (54).

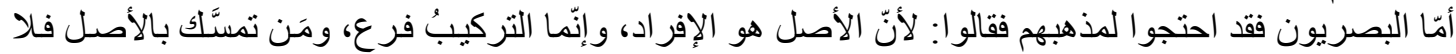

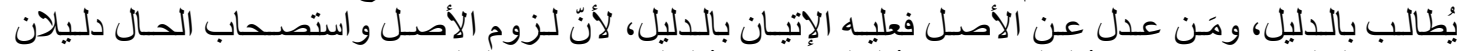

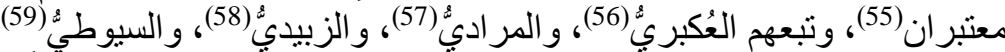

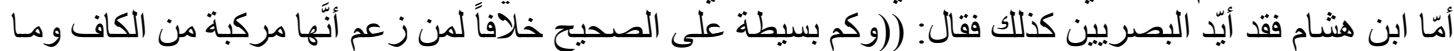

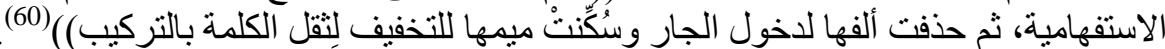

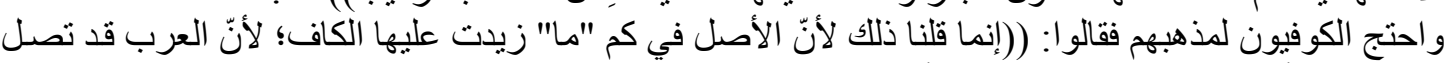

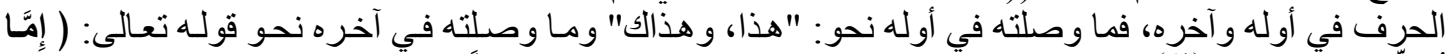

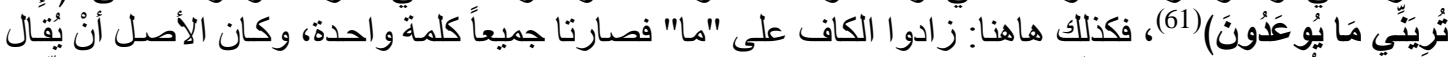

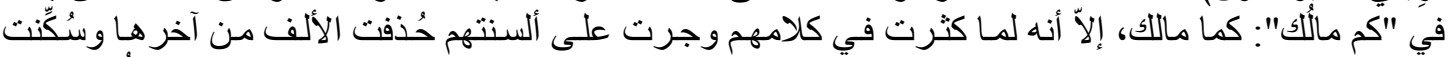

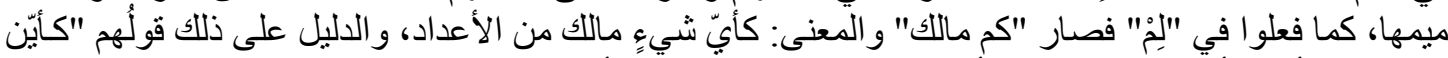

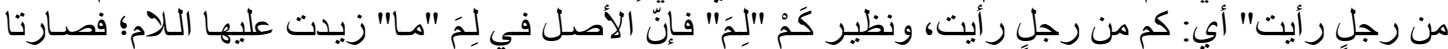

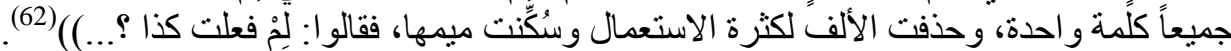

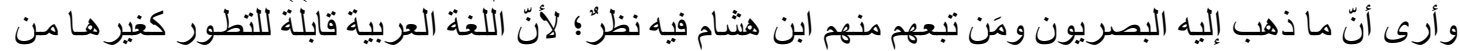

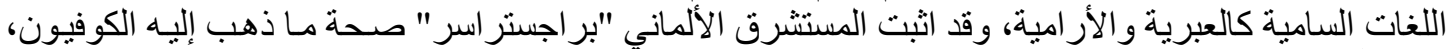

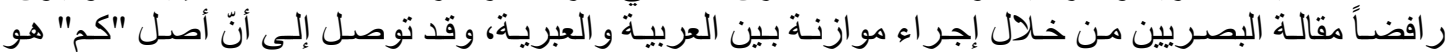
"Kame" وحذفت ألفها من آخر ها لكثرة دور إنها على اللسان (63).

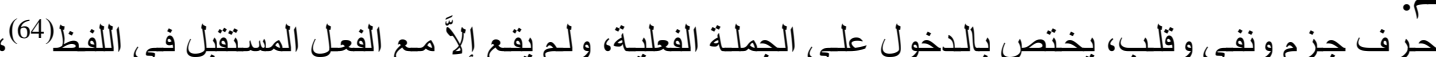

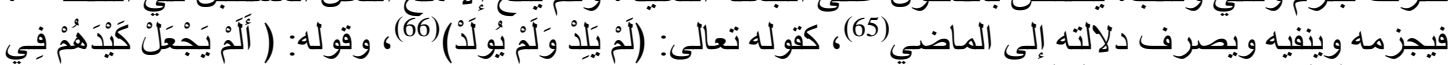
تَضْلِيل) (67)، وكقول الثناعر (68):

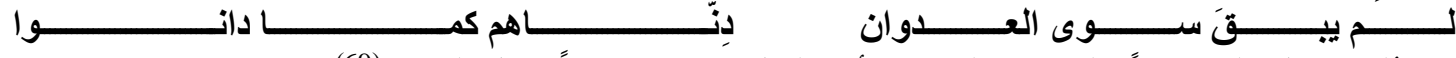
وقد يُلغى عمل "لم" حملاً على "لا" النافية، فيأتي الفعل بعدها مرفو عاً كقول الثَاعر (69):

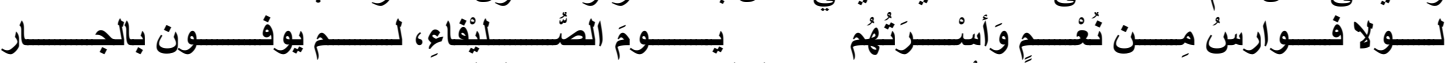

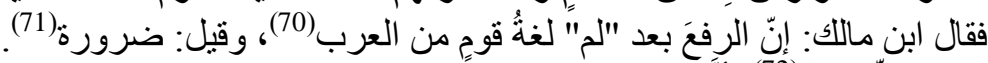

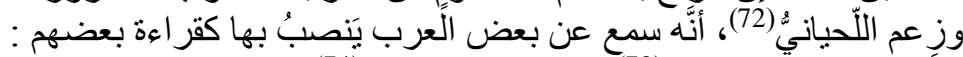

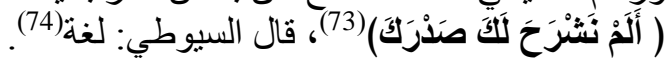

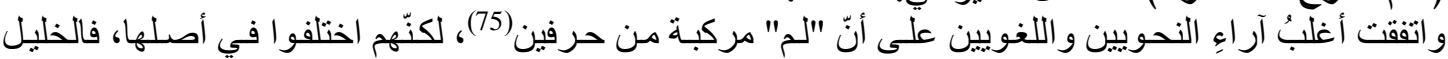

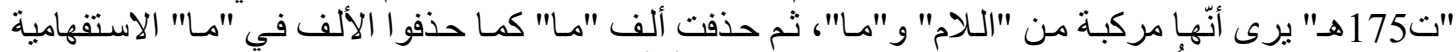

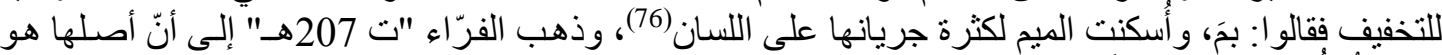

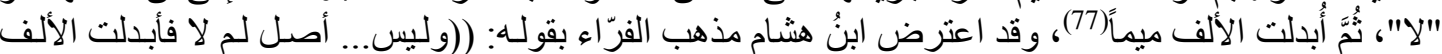

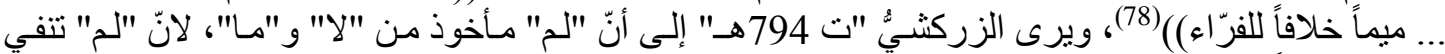

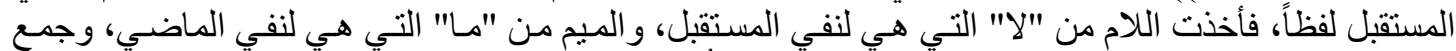

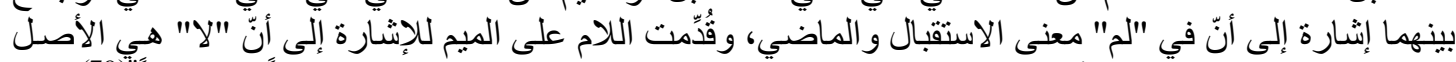

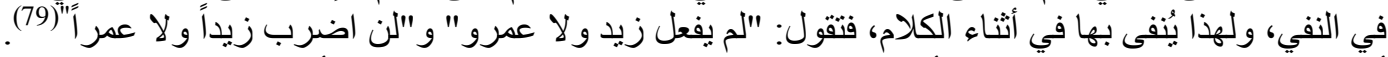

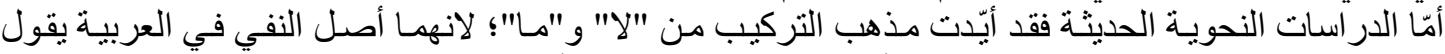

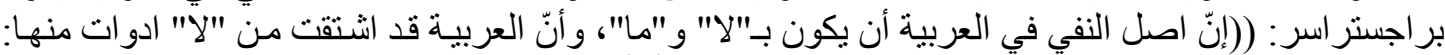
ليس، ولن... ولم: ربما كانت مركبة من "لا" و و"ما" الزائدة)) (80). 


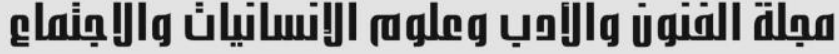

Journal of Arts, Literature, Humanities and Social Sciences www.jalhss.com

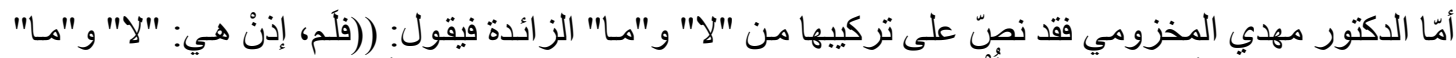

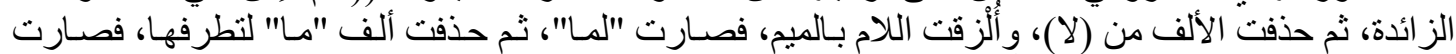

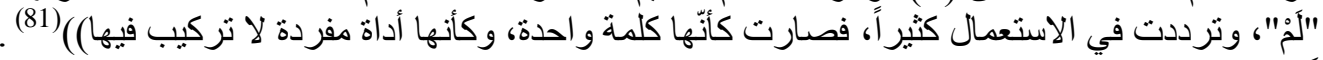

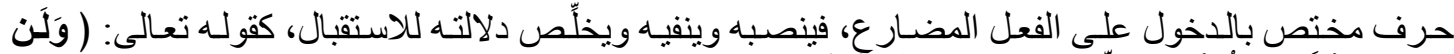

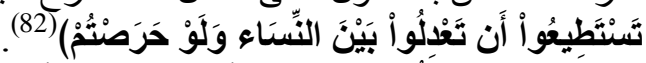

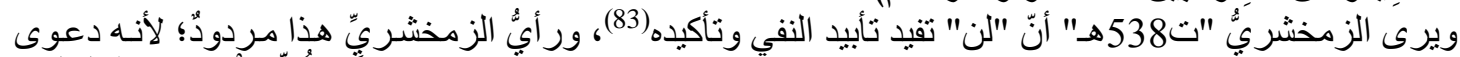

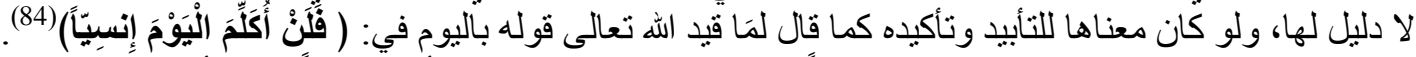

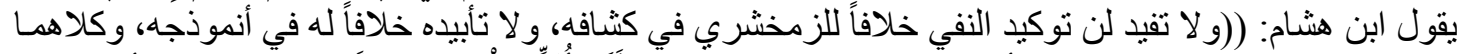

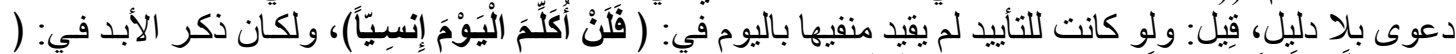

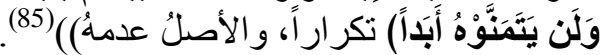

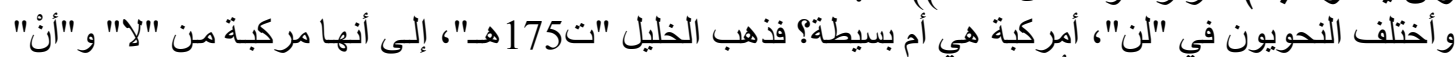

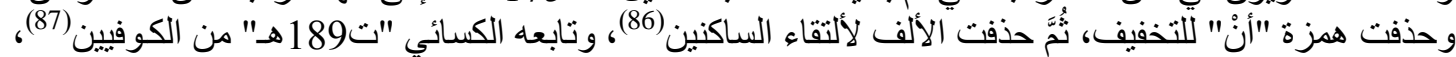

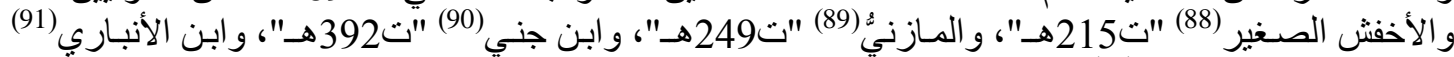

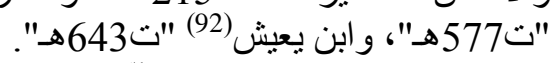

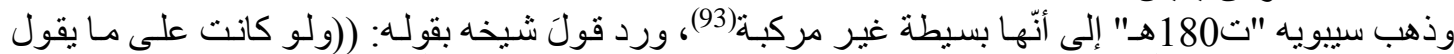

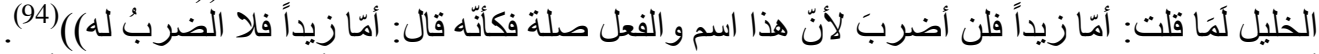

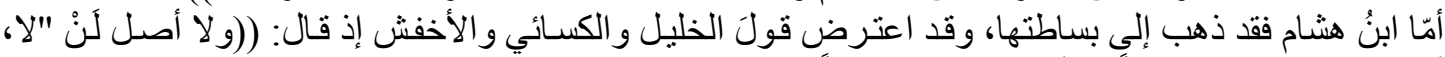

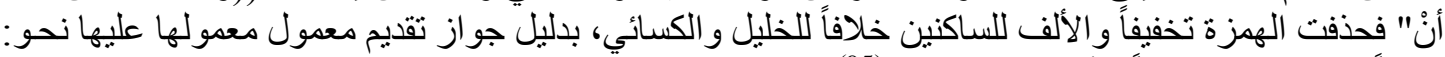

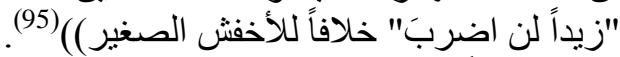

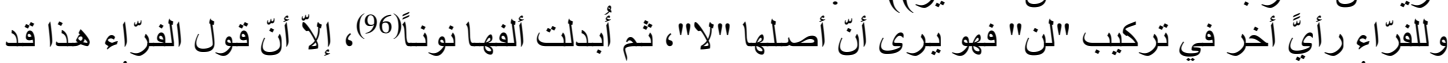
ردّه كلُّ من المر اديّ" "ت

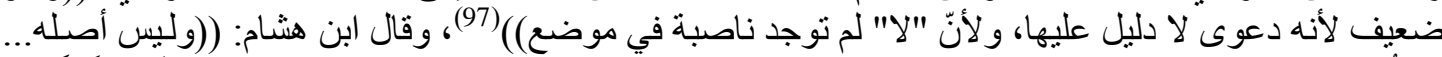

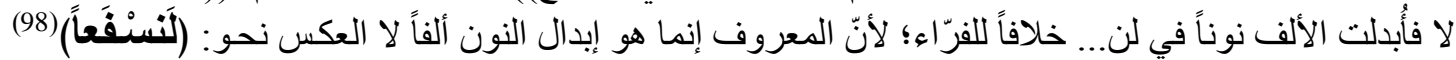

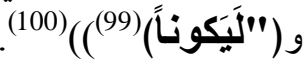

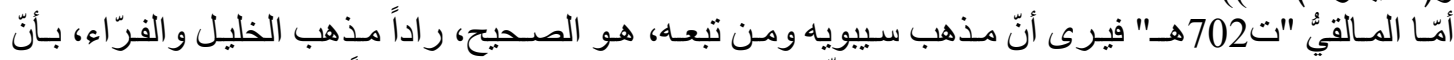

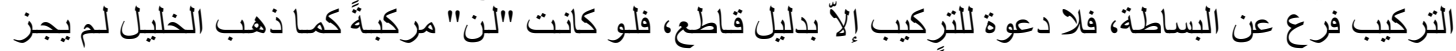

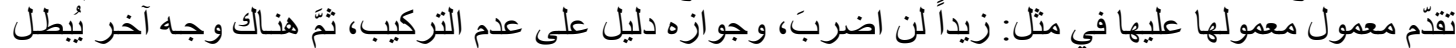

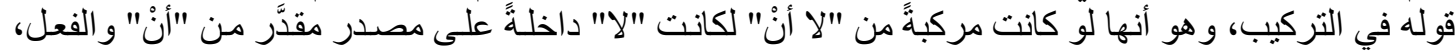

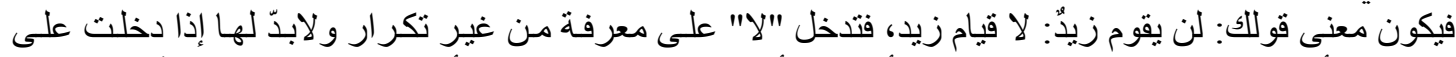

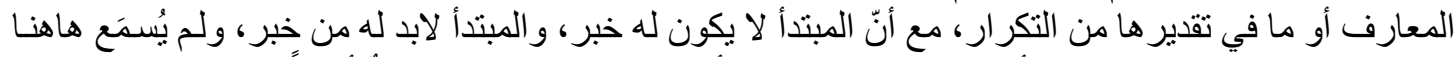

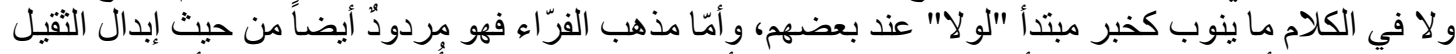

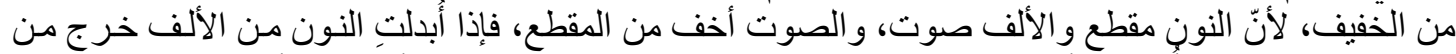

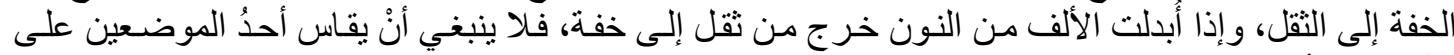

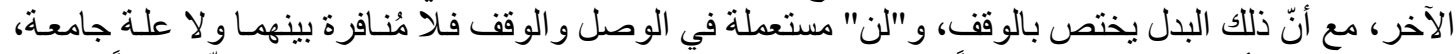

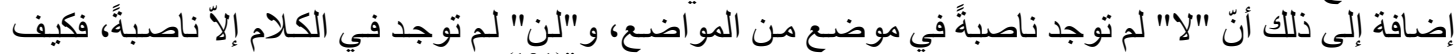

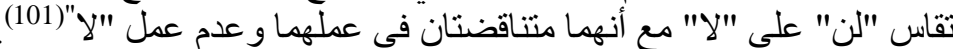

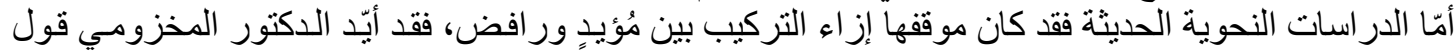

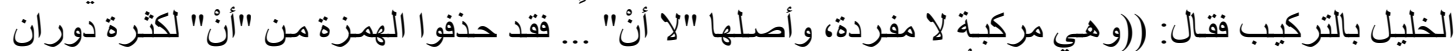

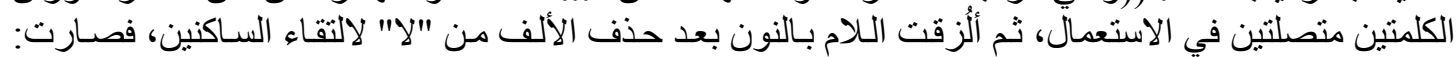

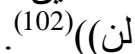
أمّا الدكتور عبده الر اجدي فرفض مقالة الخليل و الفرّاء في التركيب فقال: (("لن" حرف قائم بذاته، وليس أصله

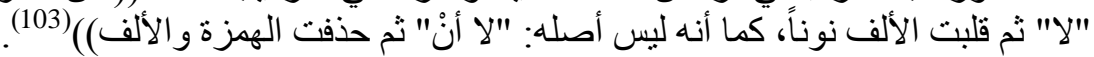




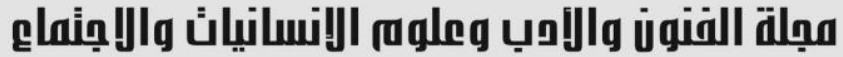

Journal of Arts, Literature, Humanities and Social Sciences www.jalhss.com

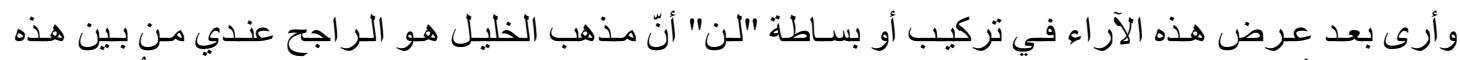

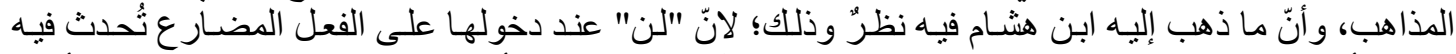

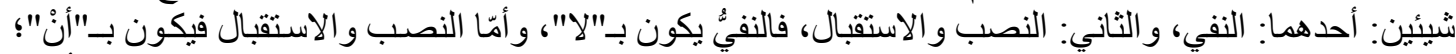

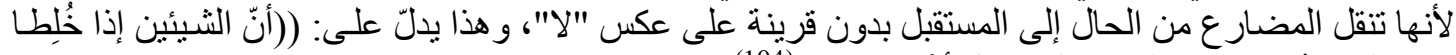

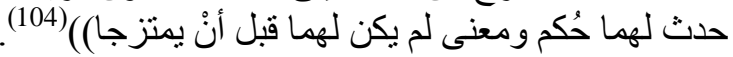

\section{الأدوات الثثلاثية}

إذن:

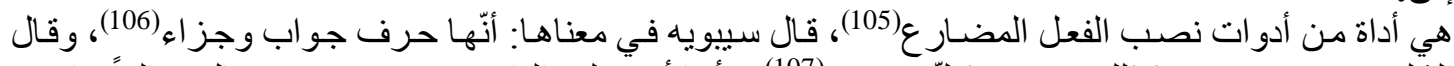

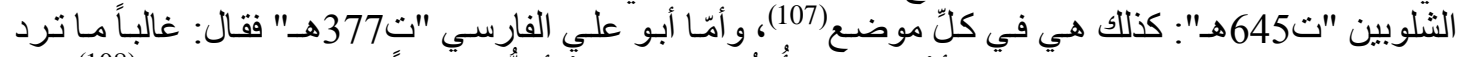

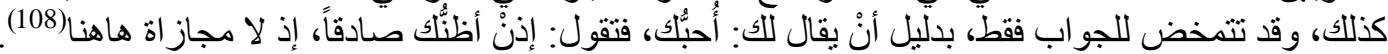

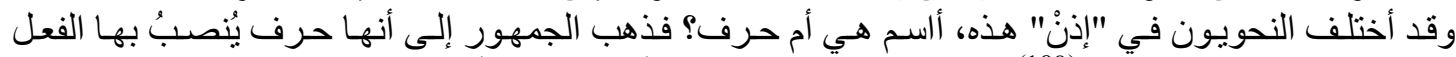

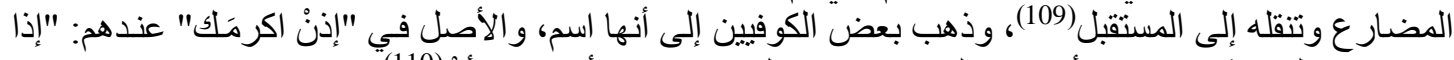

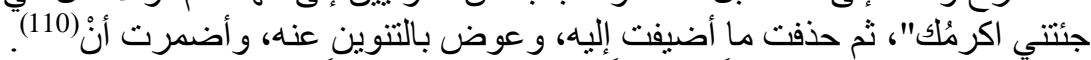

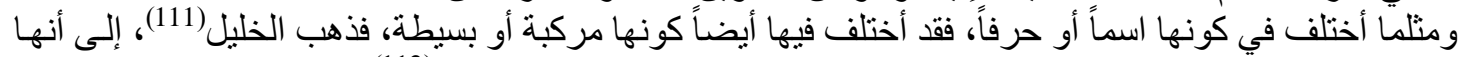

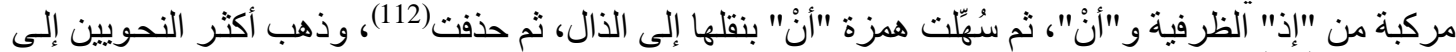
أنها بسيطة (113) - (113)

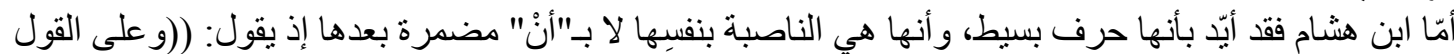

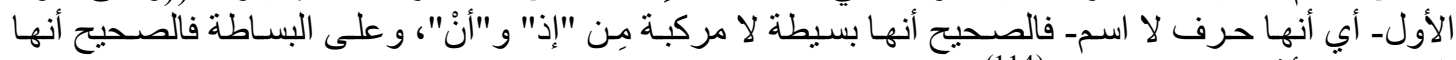

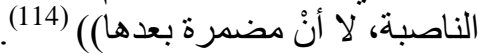

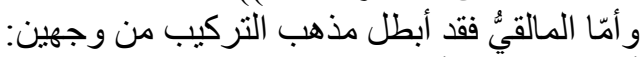

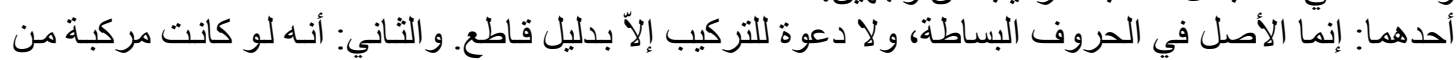

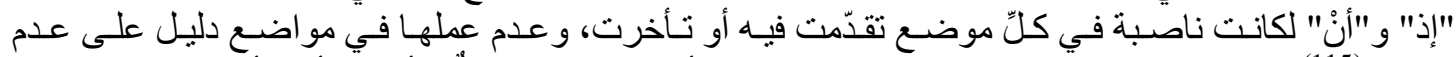

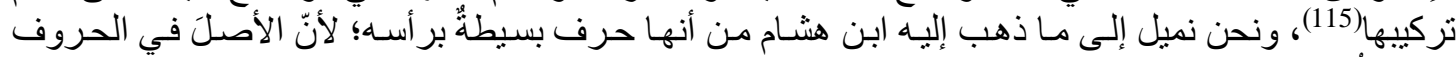

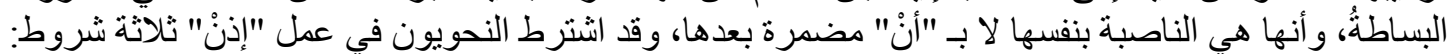

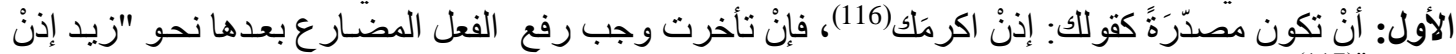

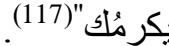

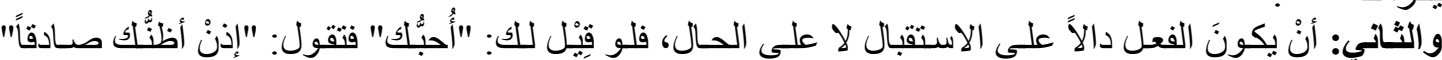

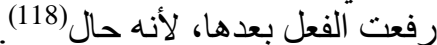

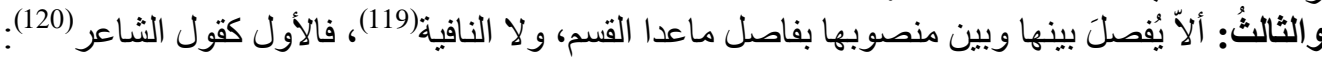

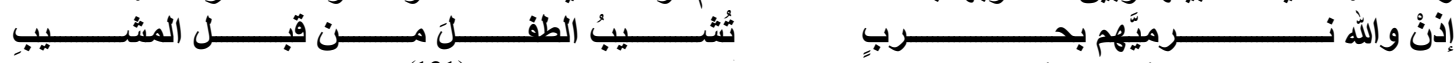

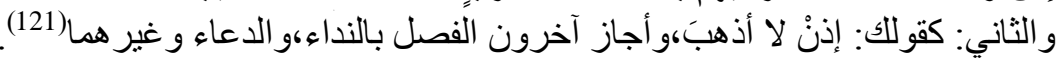

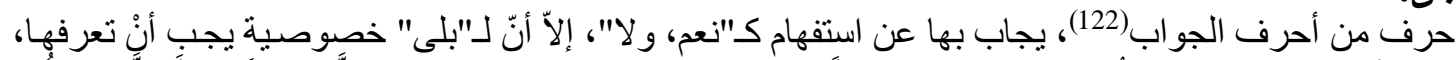

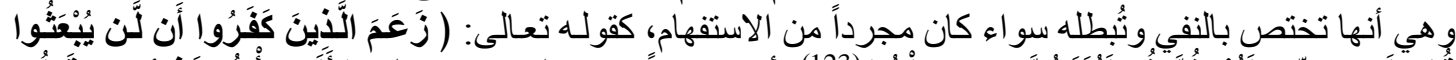

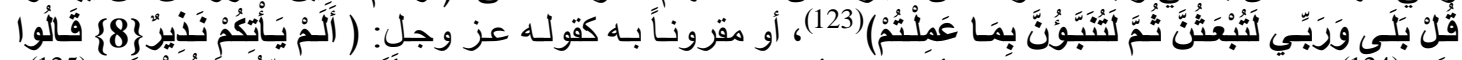

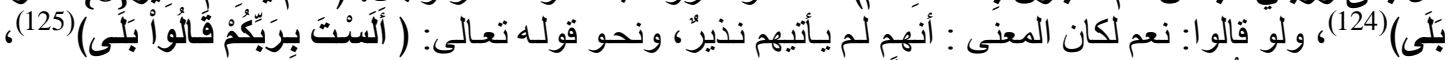

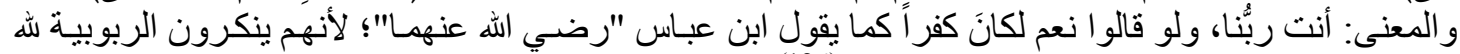

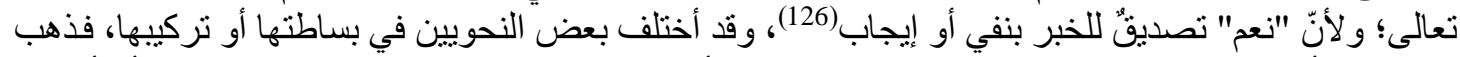

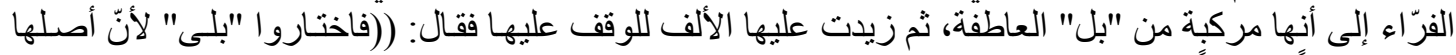

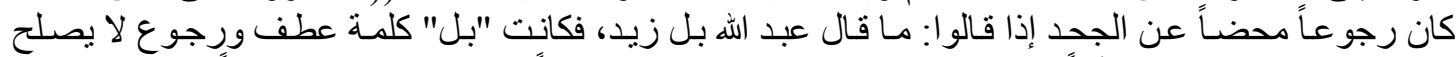

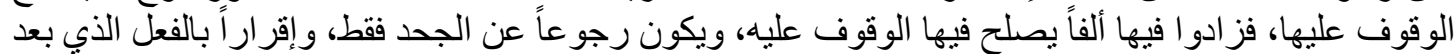

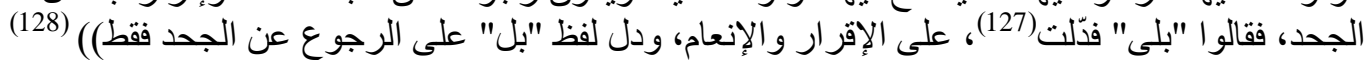




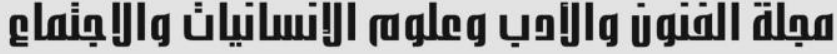

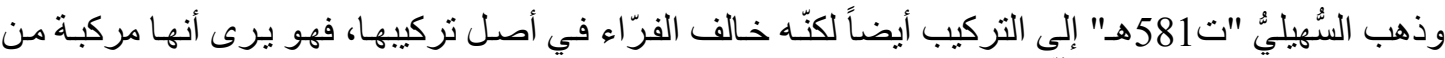

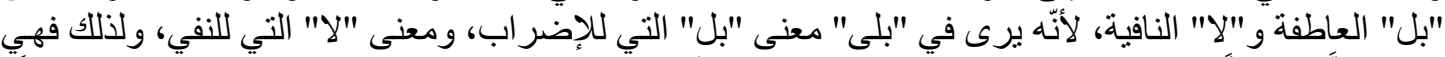

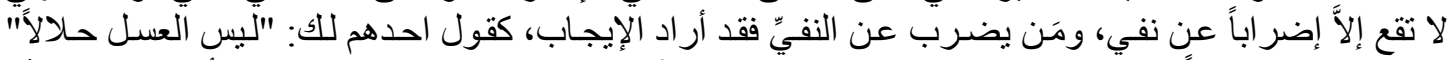

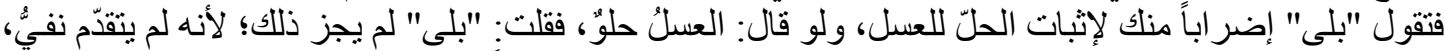

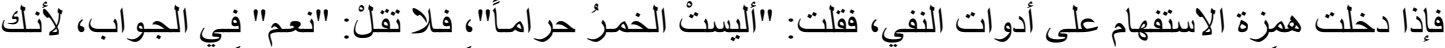

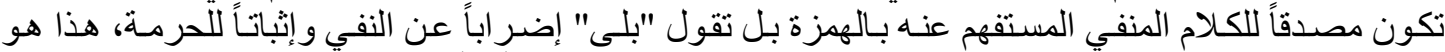

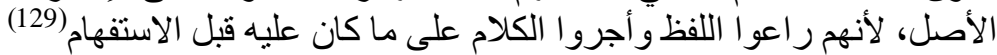

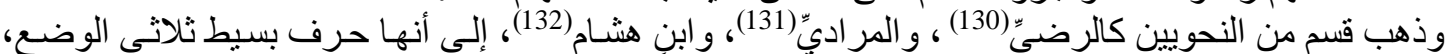

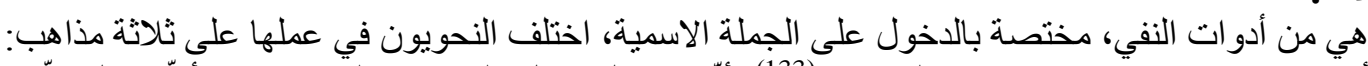

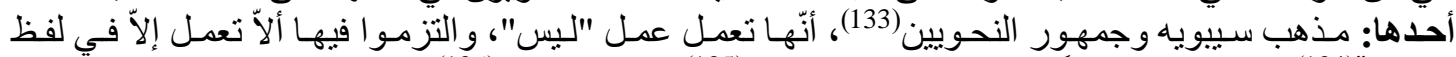

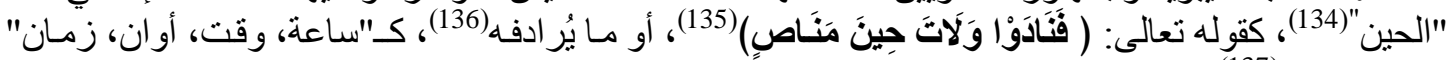

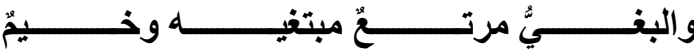

كقول الثاعر (137):

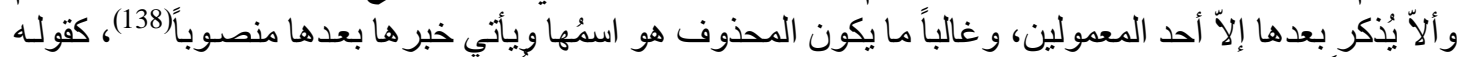

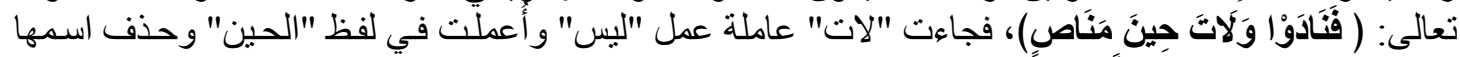

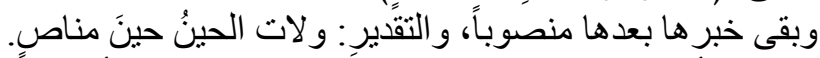

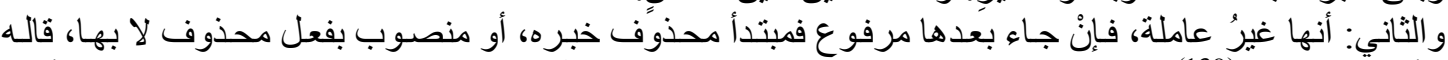

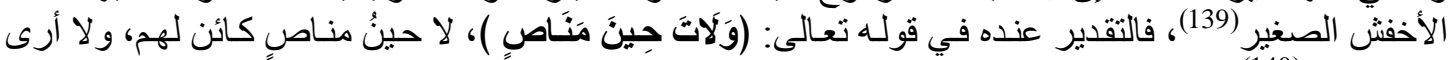

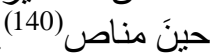

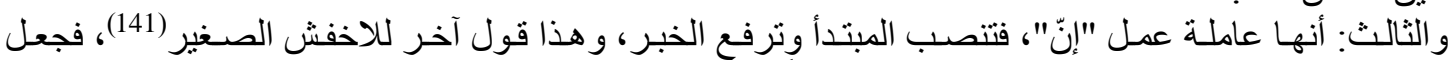

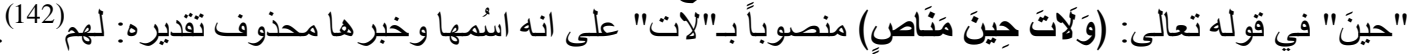

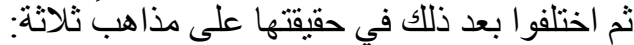

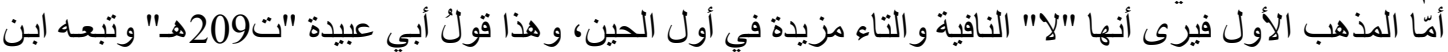

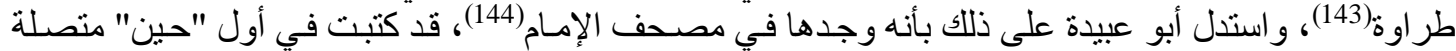

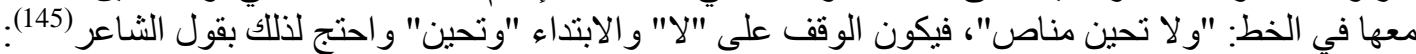

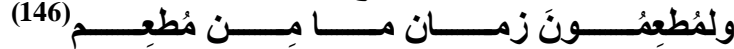

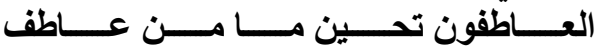

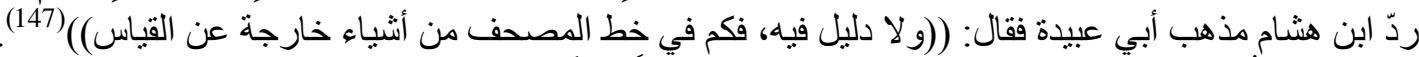

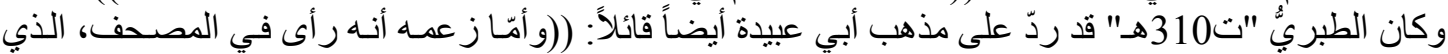

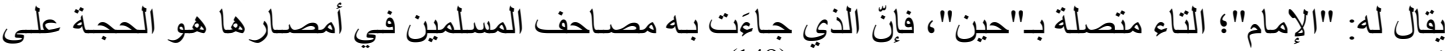

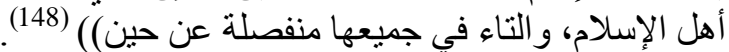

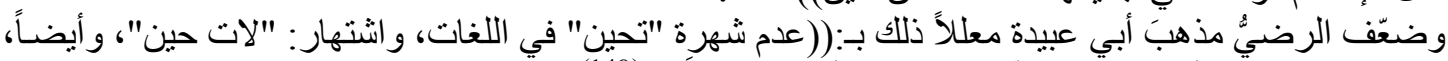

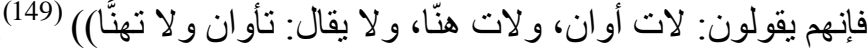

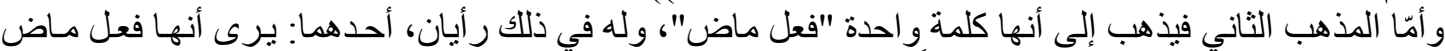

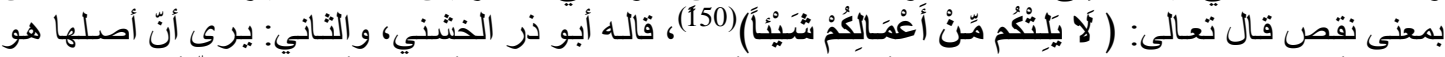

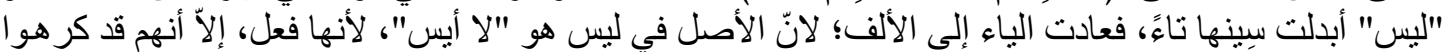

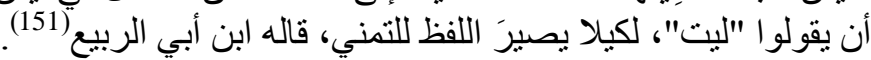

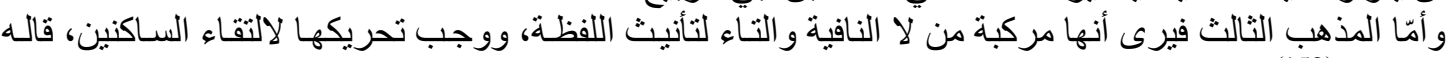
الجمهور (152). ويَشَهُُ ابن هُشام للجمهور بأنه يُوَفَف عليها بالتاء و الهاء، و أنها قد رسمت منفصلة عن الحين، وأنّ التاء قد تكسر لالتقاء الساكنين (153). 


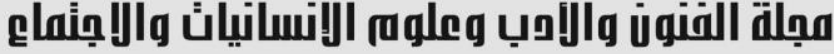

Journal of Arts, Literature, Humanities and Social Sciences www.jalhss.com

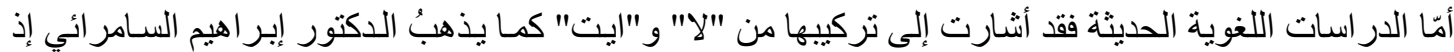

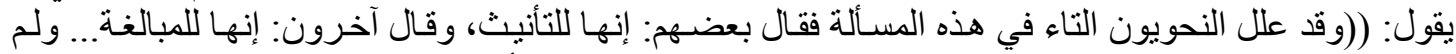
يفطنوا إلى تركيها، كما لم يفطنوا إلى تركيب "ليس" فهي مركبة من "لا أيث" فصارت في العربية "لا ايت" ثم تحولت إلى "لات اتلى () (154)

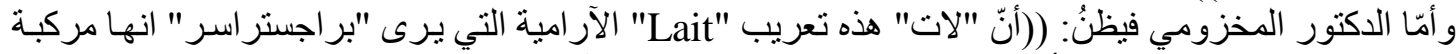

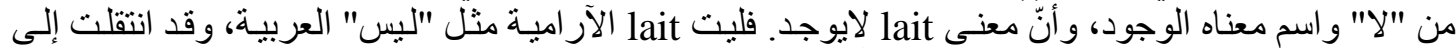

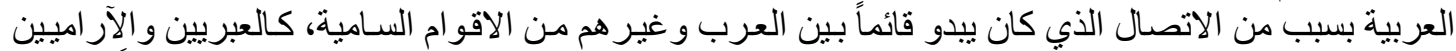

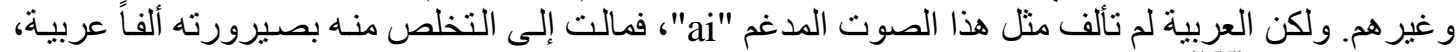

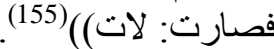

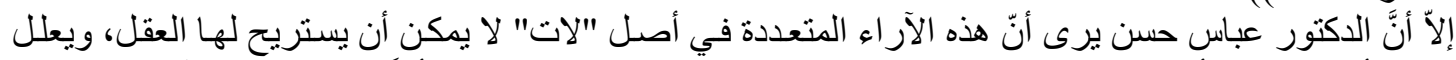

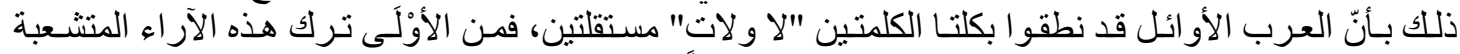

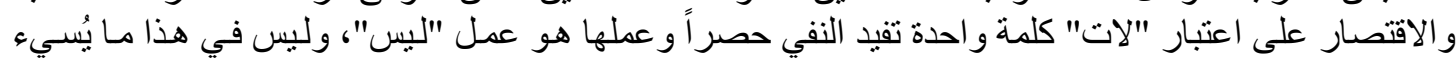

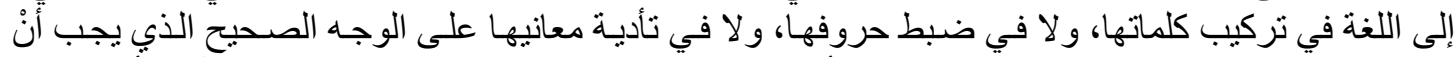

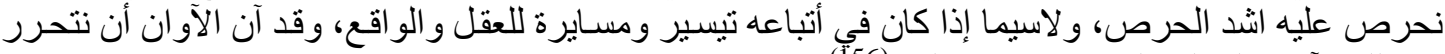
من تللك الآر اء الجدلية التي لاندئن نحتاجها اليوم(156).

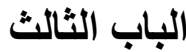 \\ الأدوات الرباعية البات}

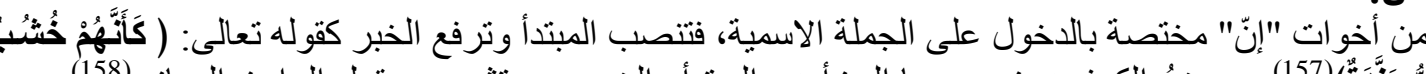

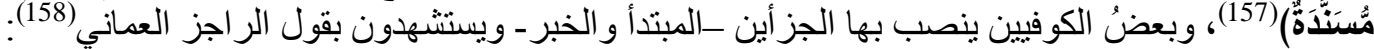

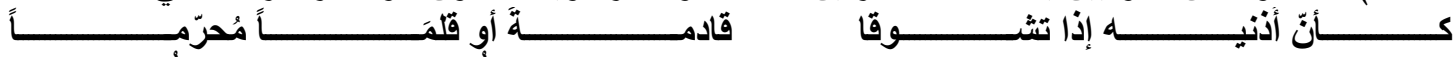

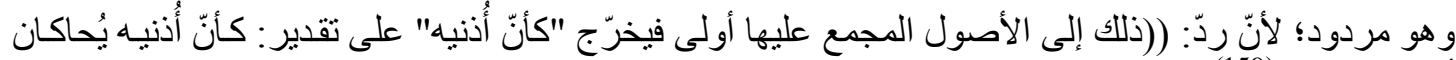

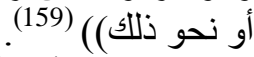

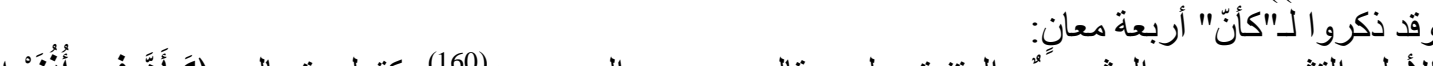

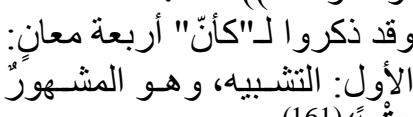

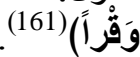
و الثاني: التقريب، و هو مذهب الكوفيين، و استدلو العلى ذلك في نحو: كأنّلك بالثتاء مُقبلّ، و المعنى تقريب الثتاء، وبقول الحريزي(162):

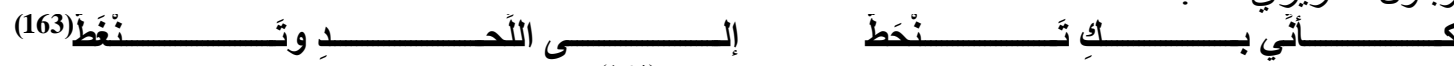

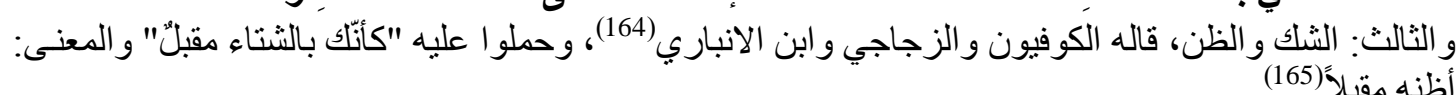
و الرابع : التحقيق، وهذا ما ذهب إليه الكوفيون و الزجاجي ، واستدلو ا عليه بقول الثاعر (166):

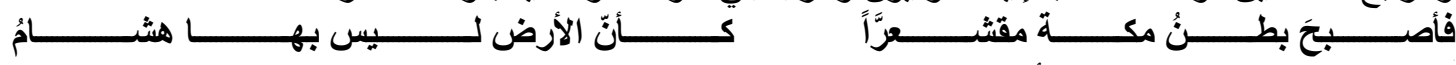

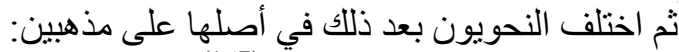

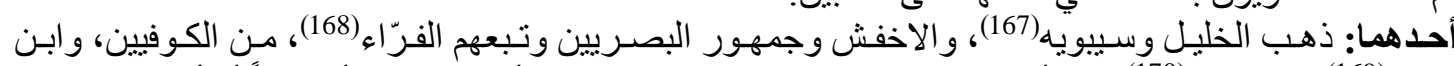

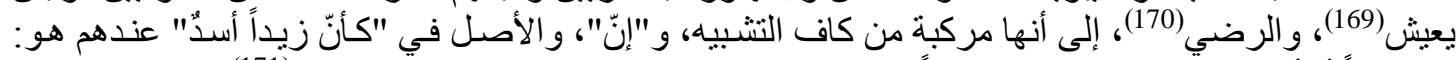

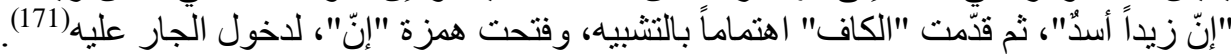

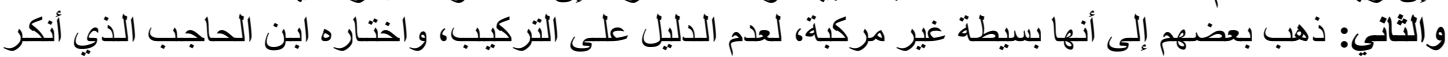

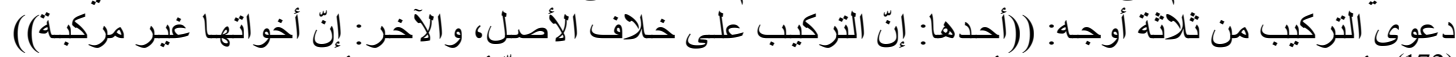

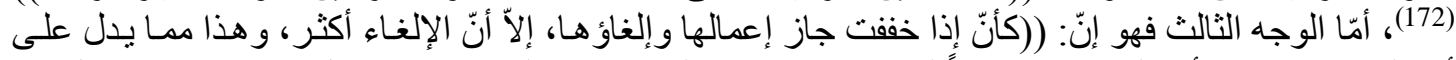

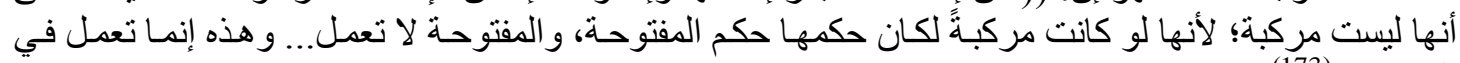
(الظاهز () (173). 


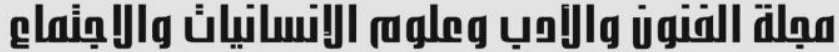

Journal of Arts, Literature, Humanities and Social Sciences www.jalhss.com

وتابعه المالقيٌ مستدلاً على ذلك بأوجه منها: إنّ الأصل في الألفاظ البساطة، و التركيب طارئ عليها، ومنها: إنها: إنها

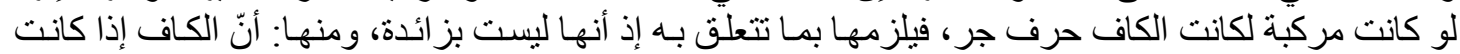

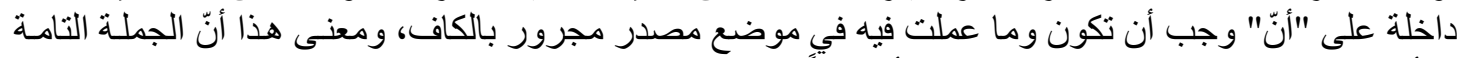

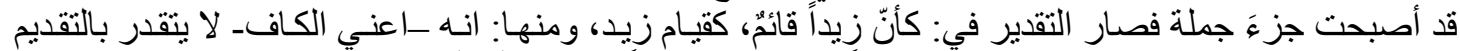

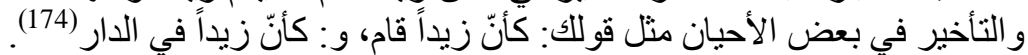

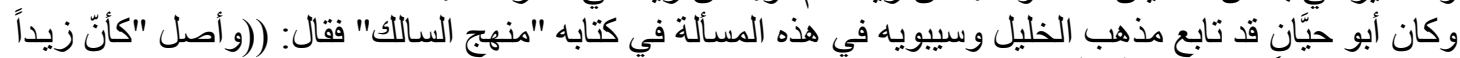

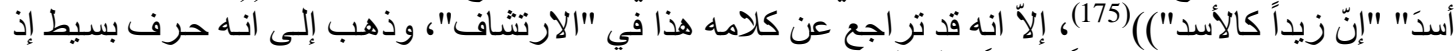

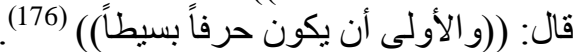

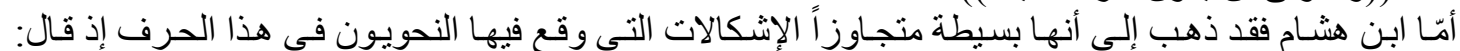

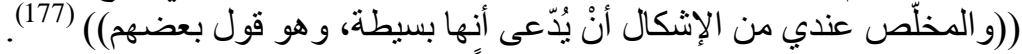

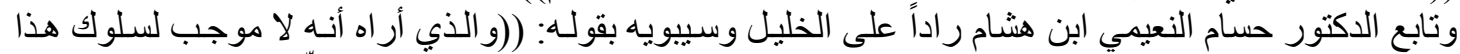

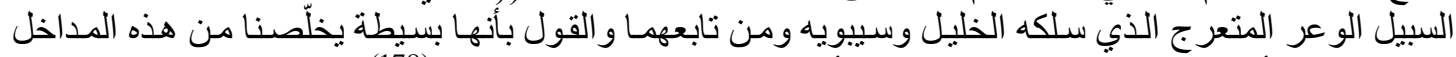

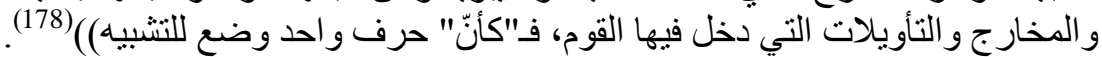

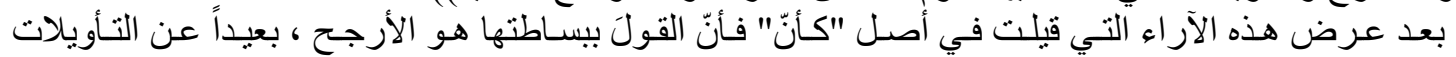

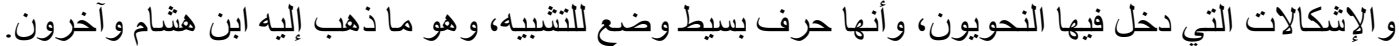

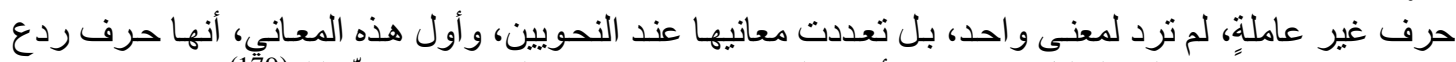

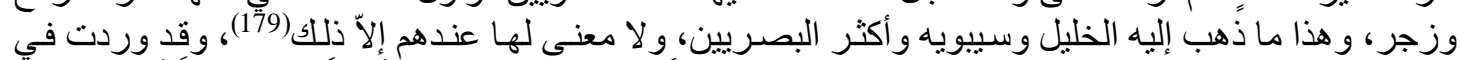

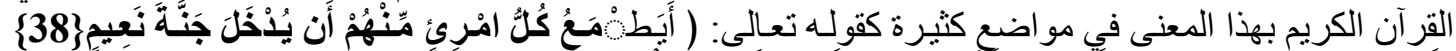

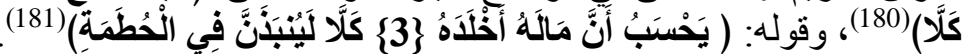

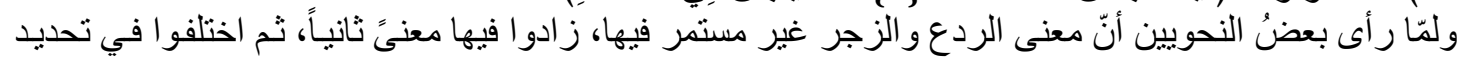

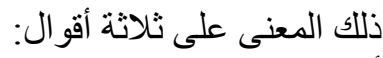

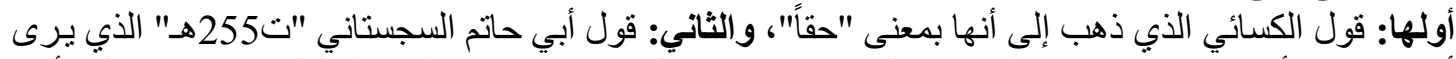

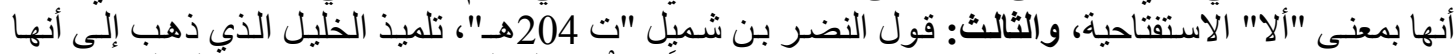

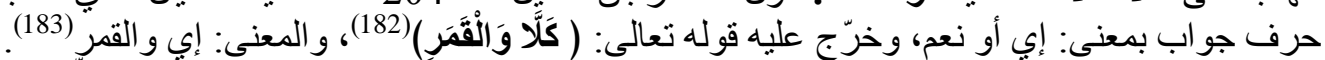

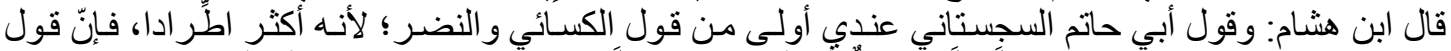

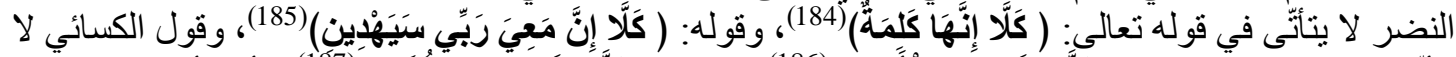

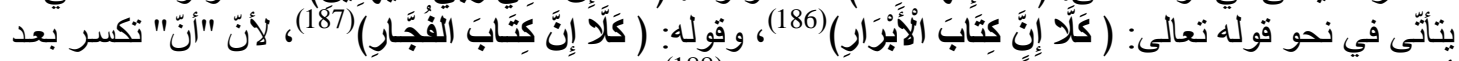

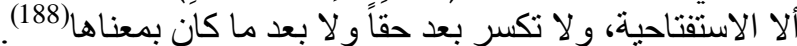

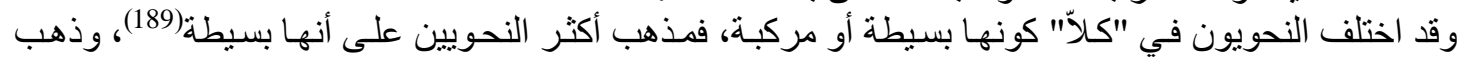

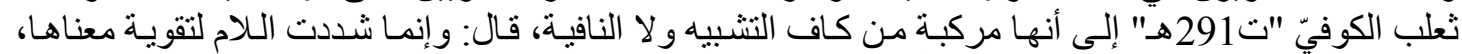

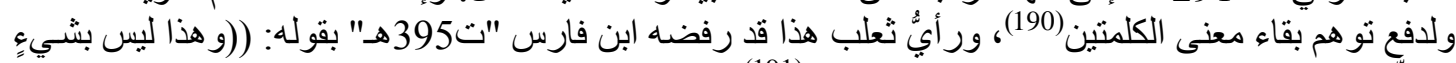

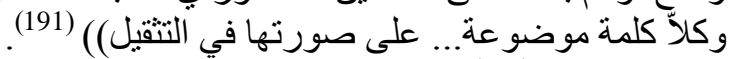

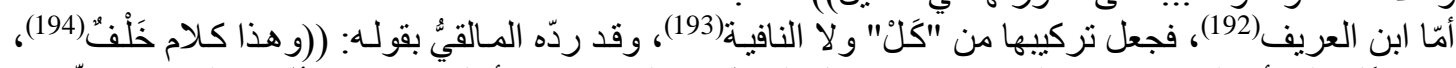

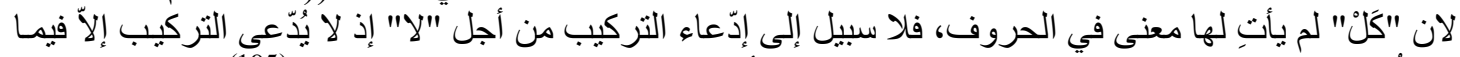

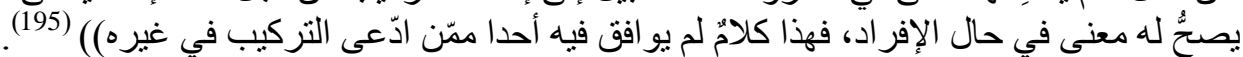

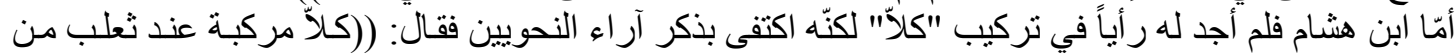

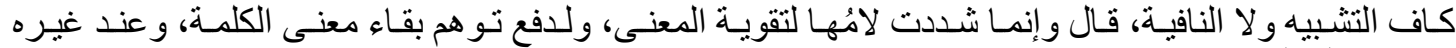
(196) (19) (الزبطة)

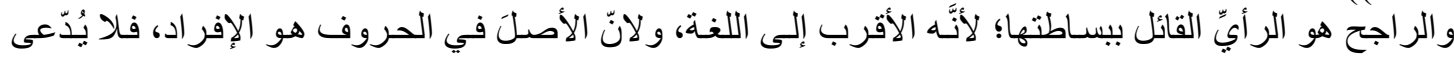
التركيب إلا بدليل قاطع.

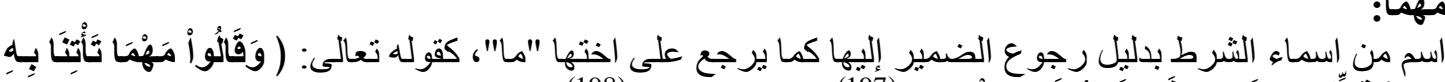

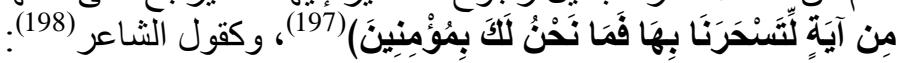




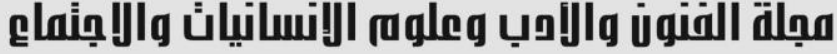

Journal of Arts, Literature, Humanities and Social Sciences www.jalhss.com

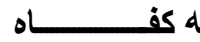

إلـ

و و

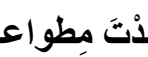

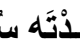

إذاذ سَـ

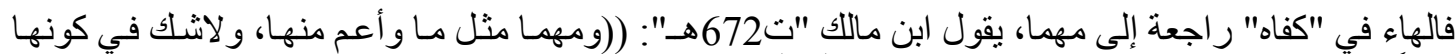

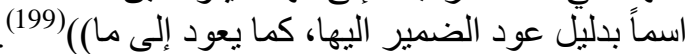

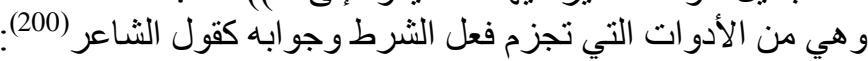

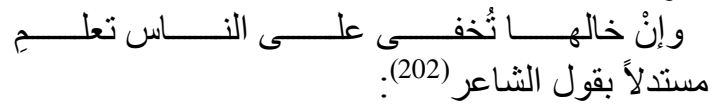

\section{6 (201)}

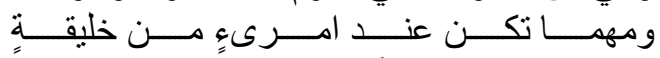

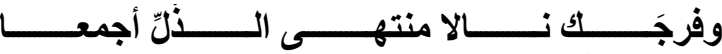

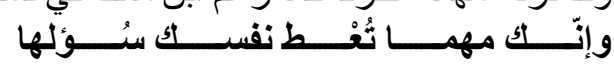

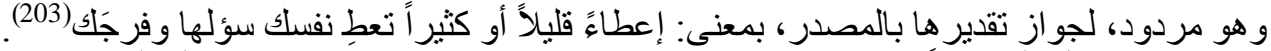

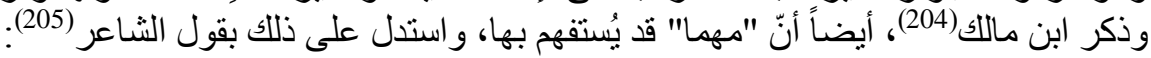

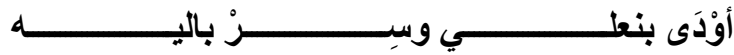

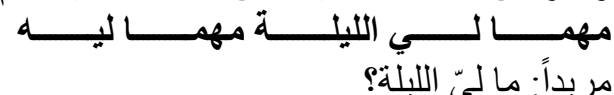

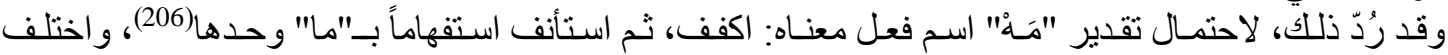

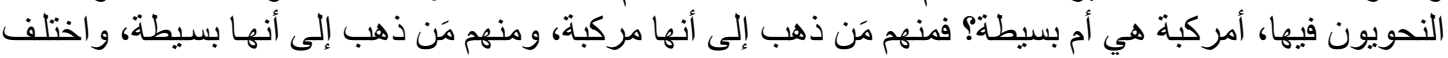

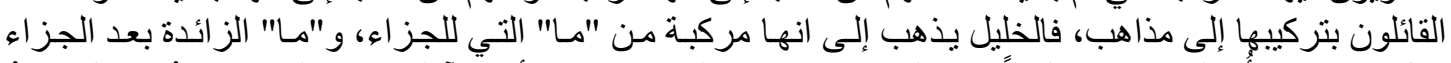

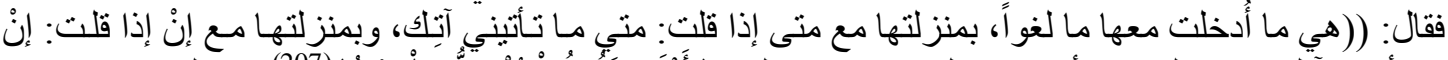

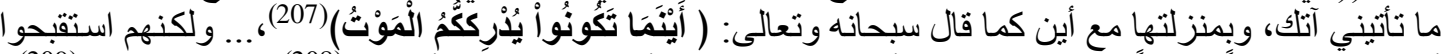

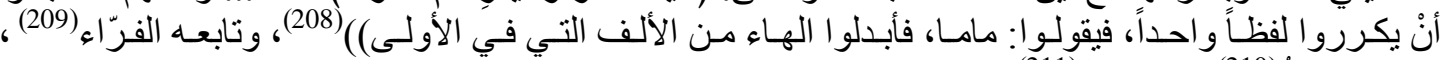

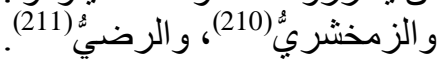

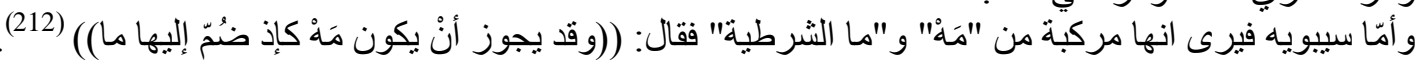

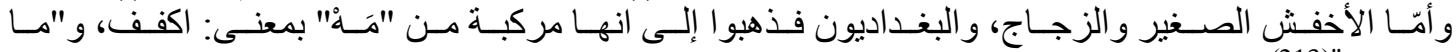
الثرطية" (213). و أمّـا الذين ذهبـوا إلـى بسـاطتها فيـرون انهـا اسـم على وزن "فعلى" و ألفهـا للتأنيـث أو للإلحساق وز ال التنـوين

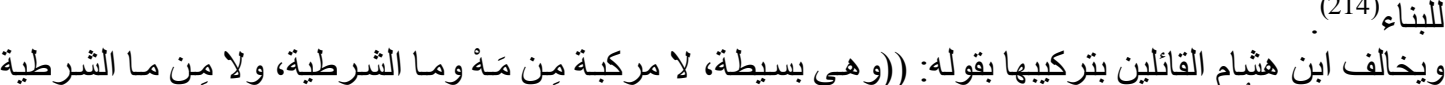

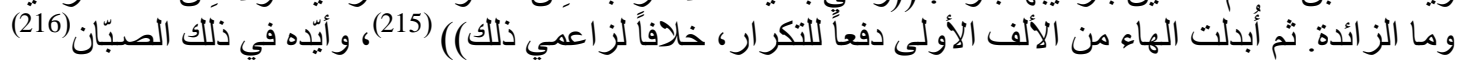

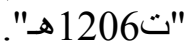

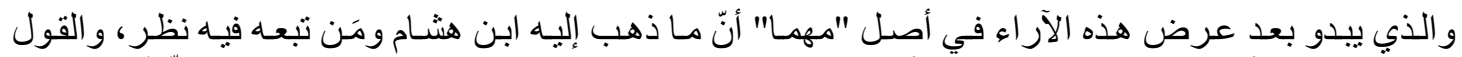

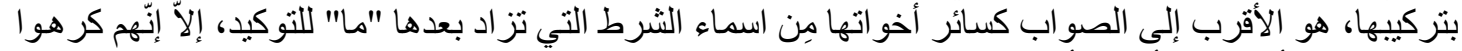
تكر ار اللفظ فأبدلو الأن ألف الأولى هاءً وقالو ا: مهما، واله اعلم.

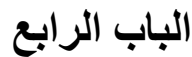 \\ الأدوات الخماسية}

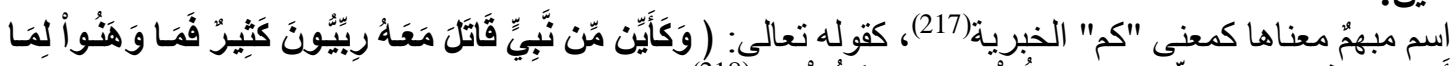

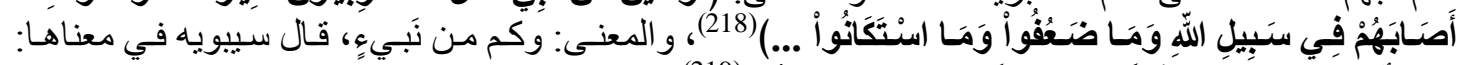

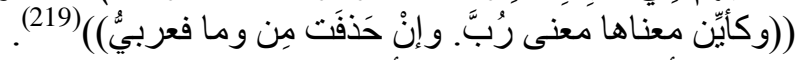

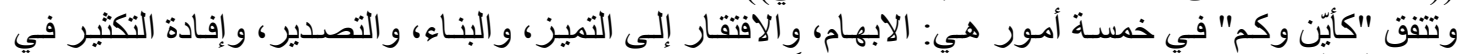

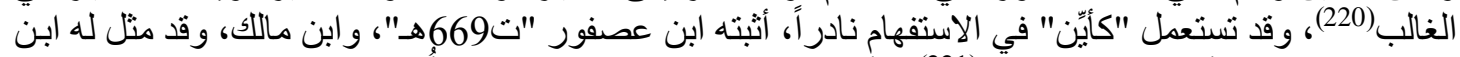

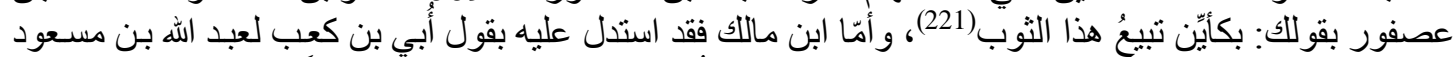

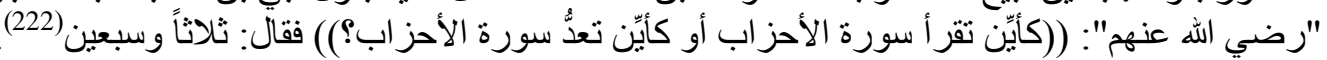

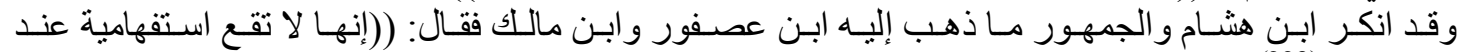

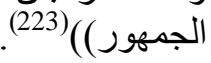




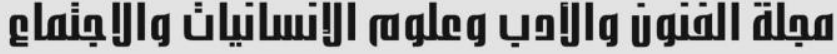

Journal of Arts, Literature, Humanities and Social Sciences www.jalhss.com

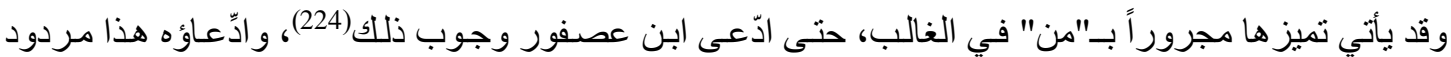

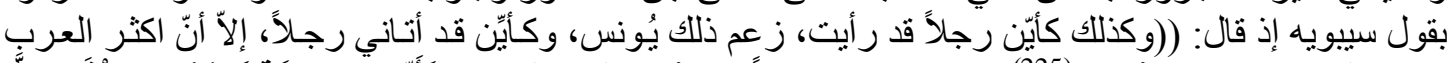

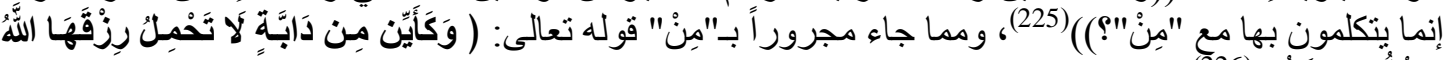

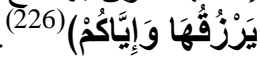

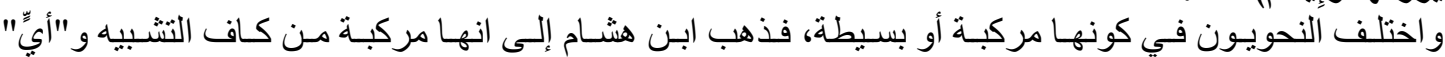

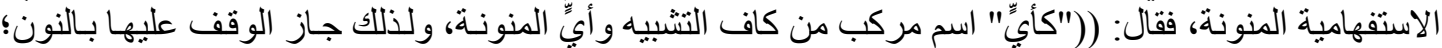

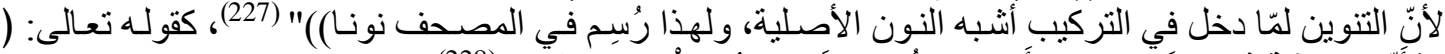

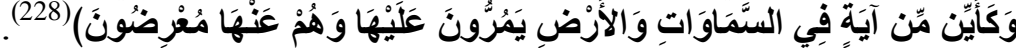

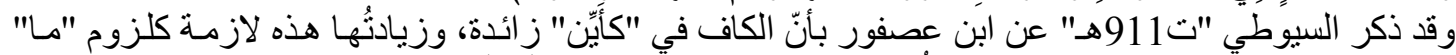

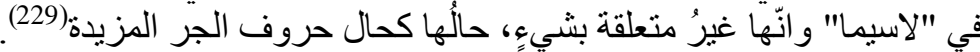

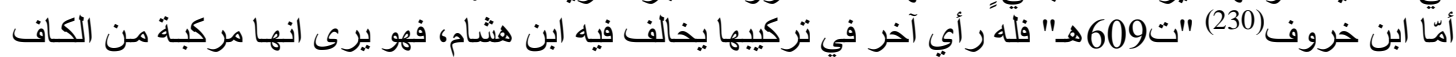

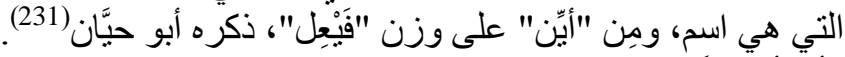

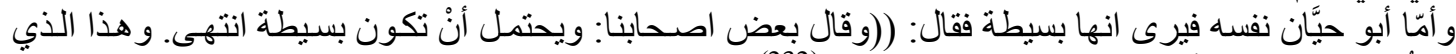

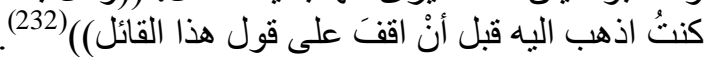

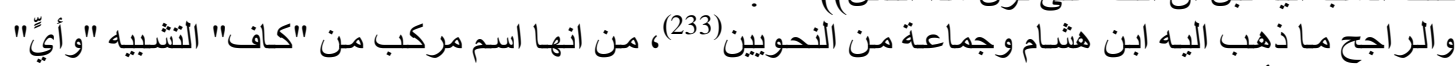

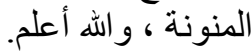

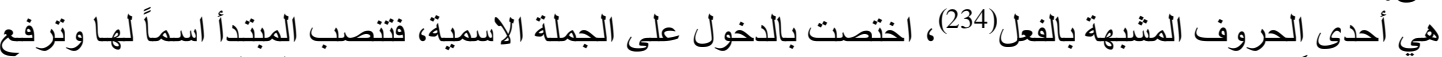

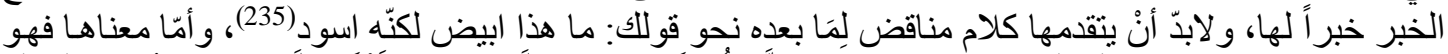

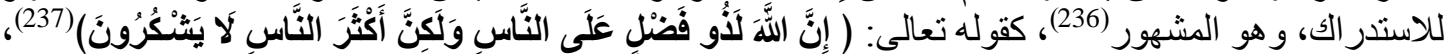

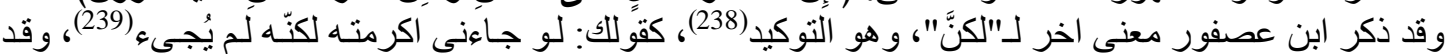

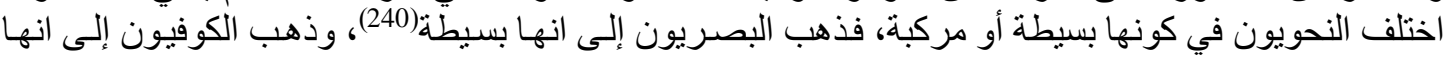

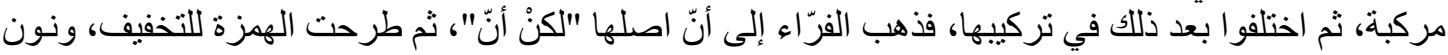

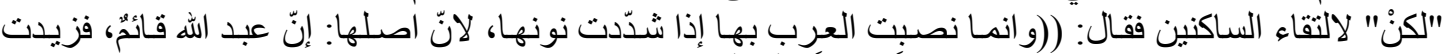

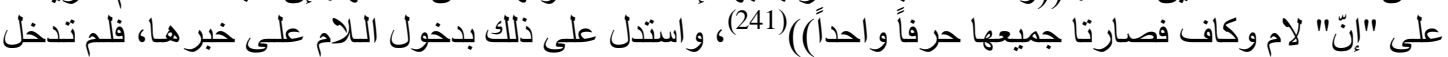

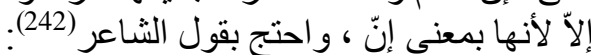

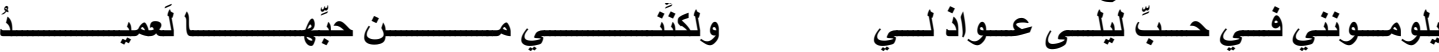

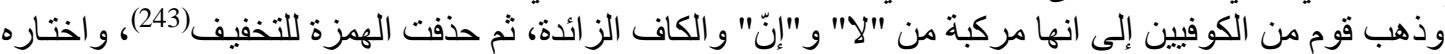

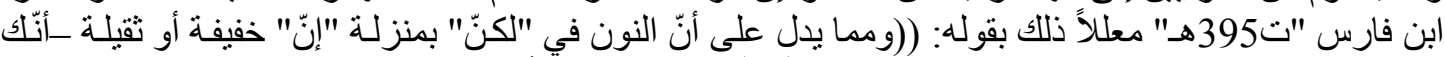

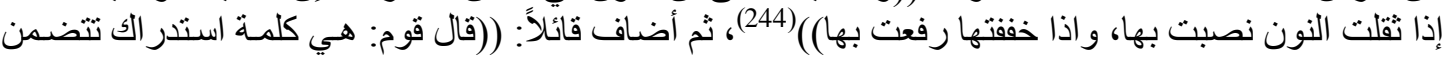

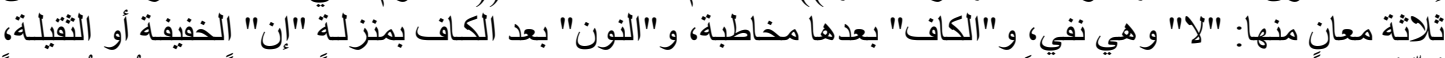

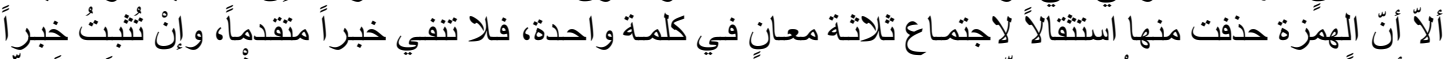

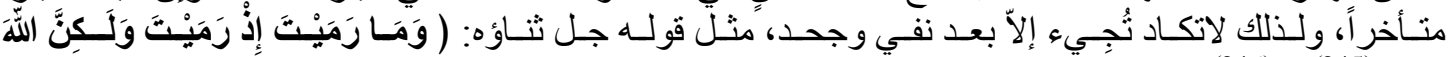

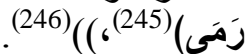
وذهب فريق ثالث من الكوفيين أيضاً: إلى انها مركبة من "لا" و "كأن" (247)، واختاره السُّهيلي معللاً اختيار مذهبه

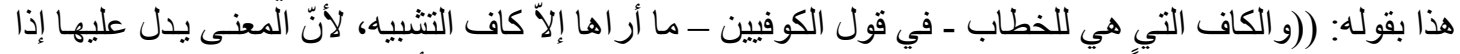

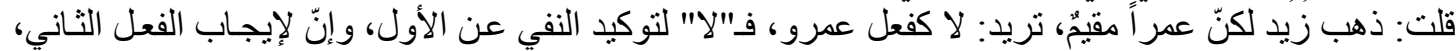

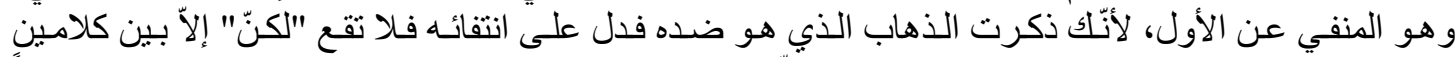

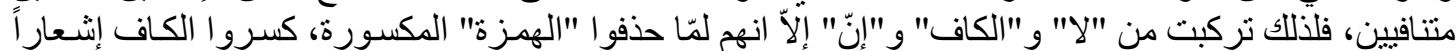
مبانا ((248)

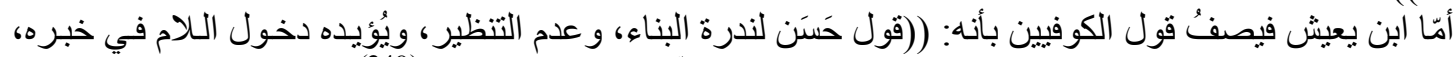

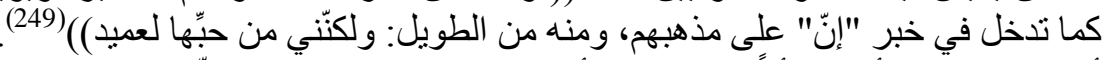

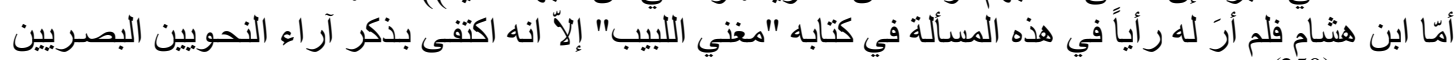
و الكو فيين (250). 


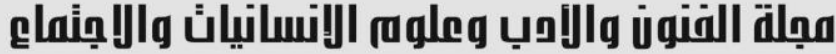

Journal of Arts, Literature, Humanities and Social Sciences www.jalhss.com

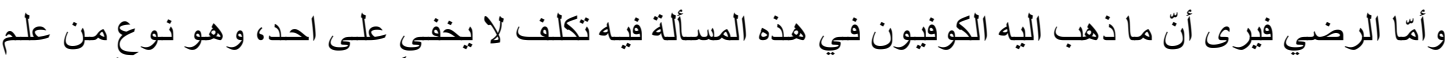

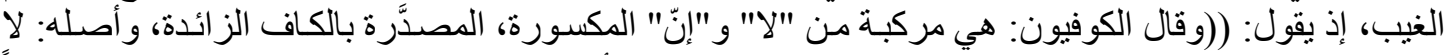

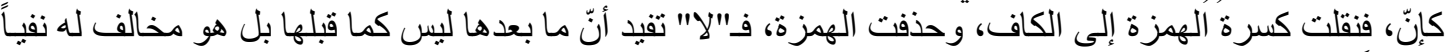

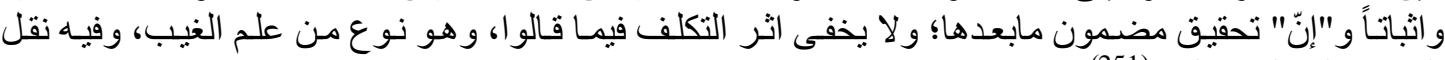

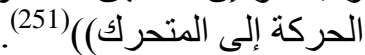

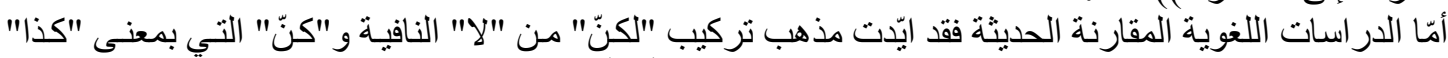

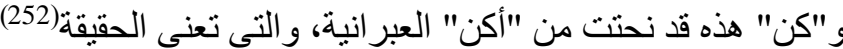

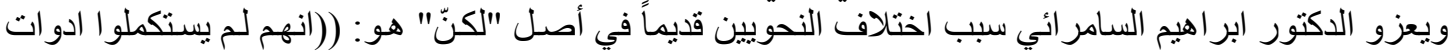

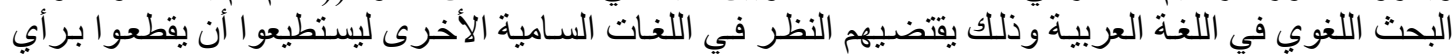

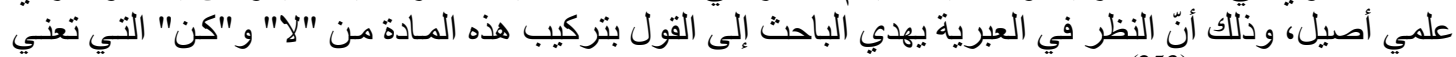
في العبرية "هكذا"()(أن (253).

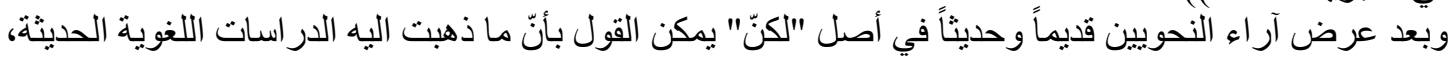
هو الر اجح عندي، بسبب التداخل الحاصل بين العربية وبين أخو اتها اللغات السامية، ولان والعبرية، و الآرامية.

الخاتمة والنتائج

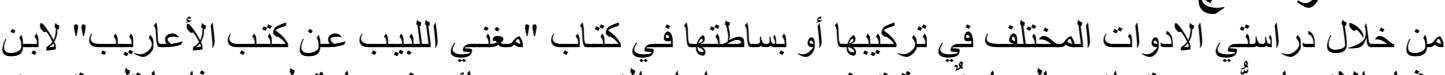

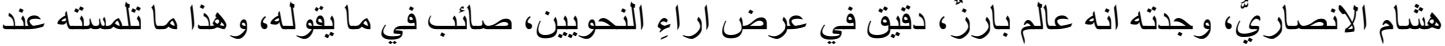
ابن هشام في كتابه، وقد توصن التهن البحث إلى النتائج الاتية:

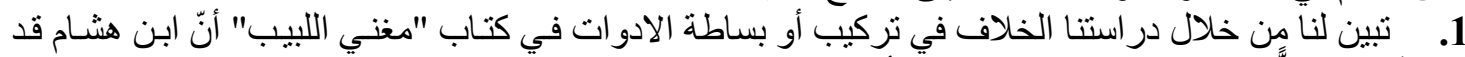

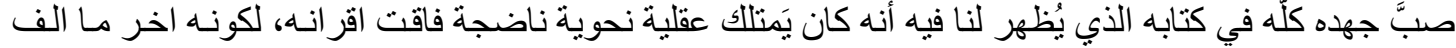
من كتباه.

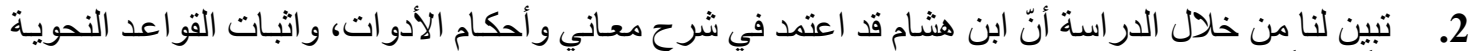

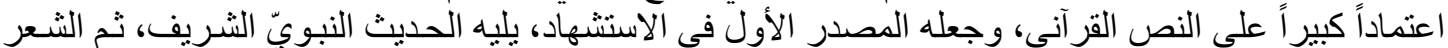

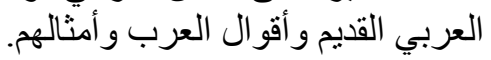

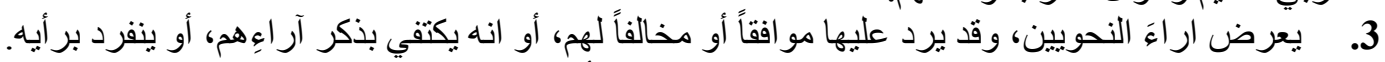

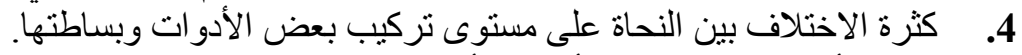

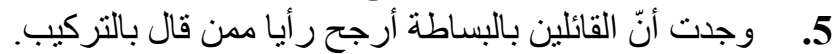
6. 7. قد تكون الأدو ات وهي بسيطة أقرب إلى الواقع وبعيدة عن التكلف مما لو كانت مركبة.

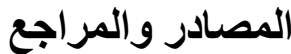

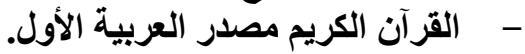

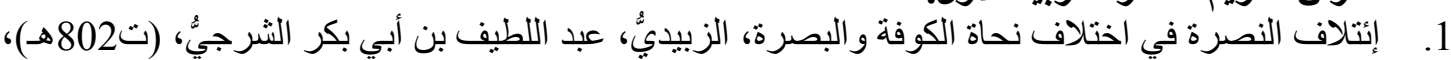

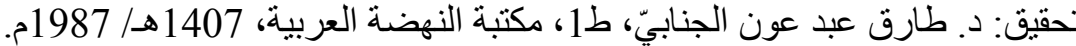
2.

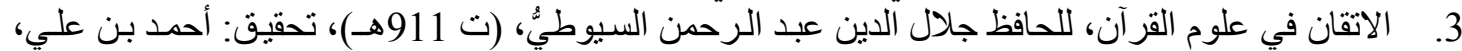

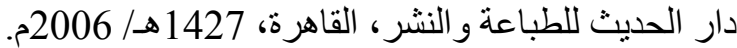

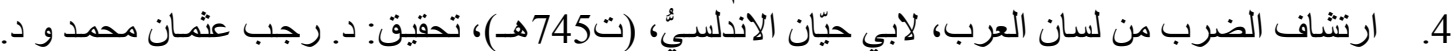

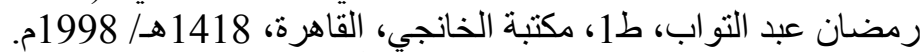

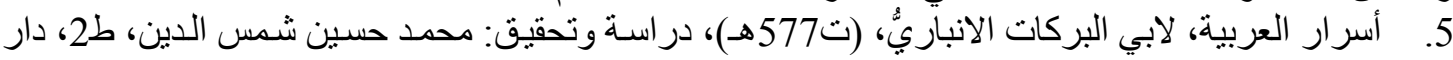

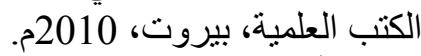

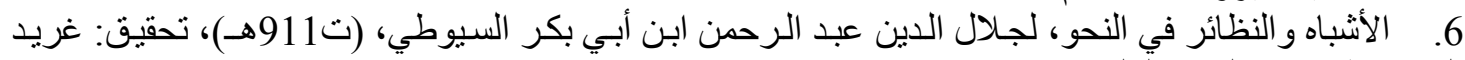

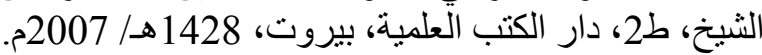




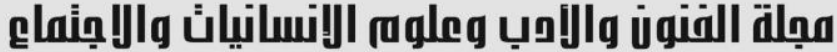

Journal of Arts, Literature, Humanities and Social Sciences www.jalhss.com

7. اعر اب ثلاثثن سورة من القرآن الكريم، لأبي عبد الله الحسين بن أحمد المعروف بـابن خالويـة، (ت370هـ)، دار التربية للطباعة و النشر.

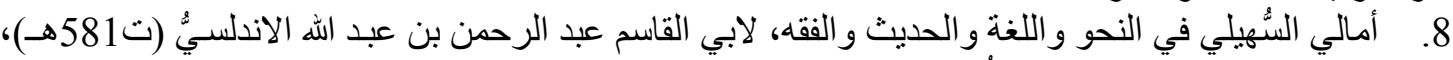

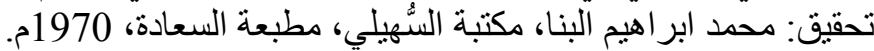

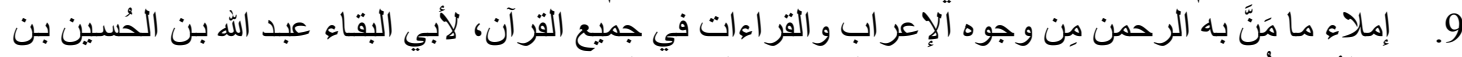

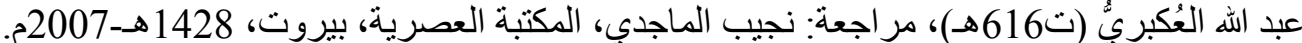

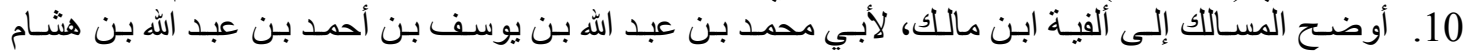

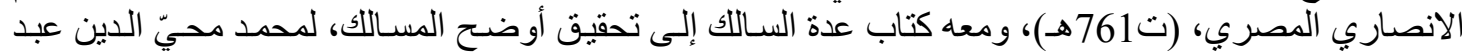

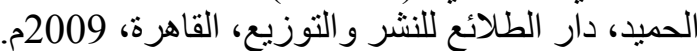

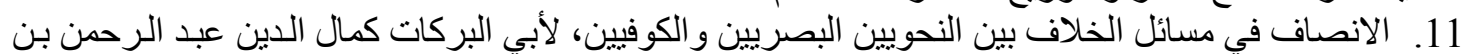

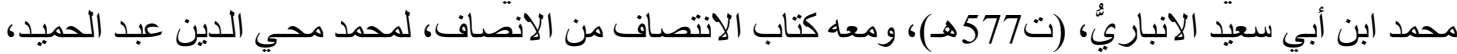

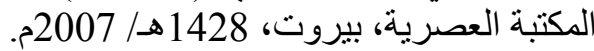
12. الايضاح في شرح المفصل، لأبن الحاجب النحويُ، تحقيق: د. موسى بنـاي العليلي، مطبعة العاني، بغداد،

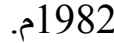
13. البرهان في علوم القرآن، للامام بدر الدين محمد بن عبد الله الزركثي، تحقيق: محمد أبو الفضل ابر اهيم،

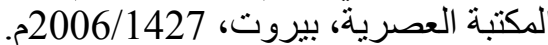

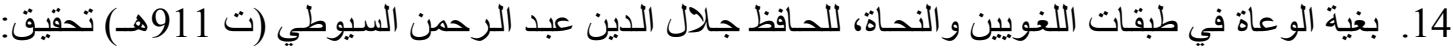

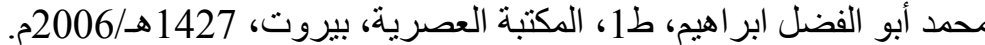

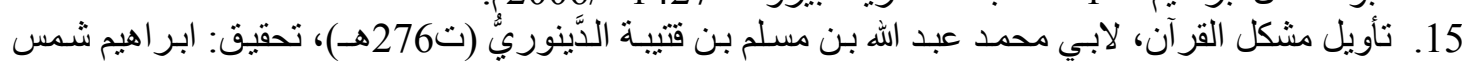

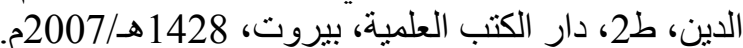

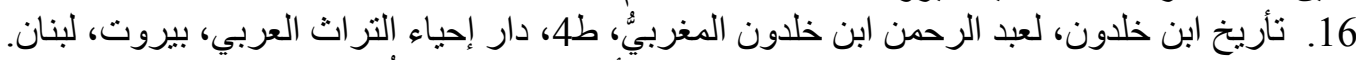

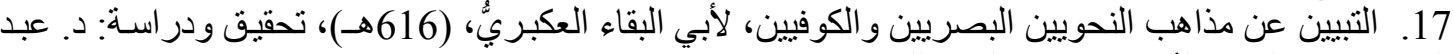

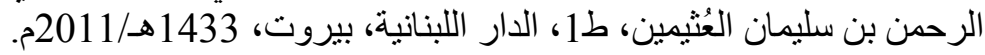

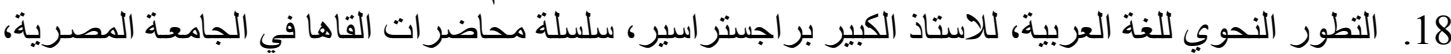
1929م. 1929 - n

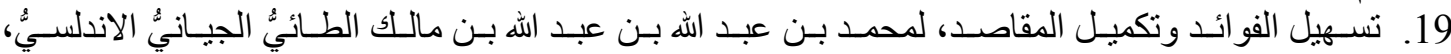

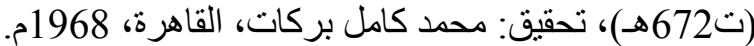

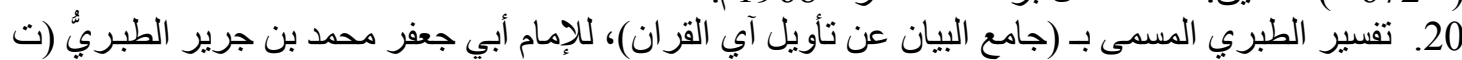

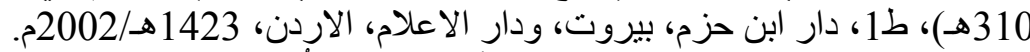

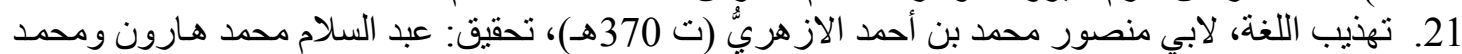

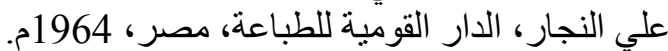

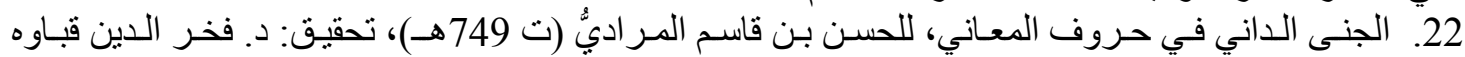

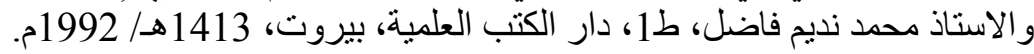

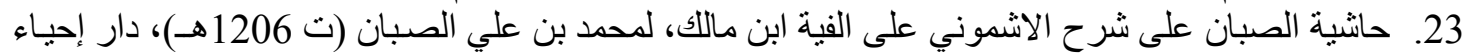

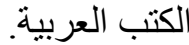
24. الدرر الكامنة في أعبان المئة الثامنة، لثيخ الإسلام شهاب الدين العسقلانيُ، (ت هـ)، تحقيق: محمد سيد جاد الحق، مطبعة المدني.

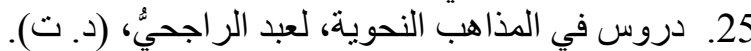

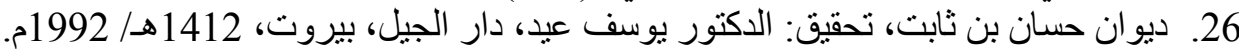

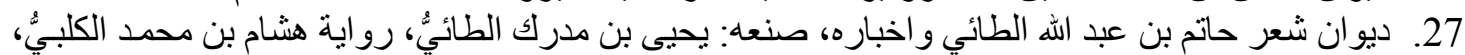
تحقيق: د. عادل سليمان جمال، مطبعة المدني. 28. رصف رصف المباني في شرح حروف جان المعاني، للإمام أحمد بن عبد النور المالقيٌ (ت 702هـ)، تحقيق: أ. د. احمد

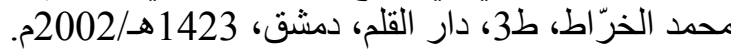




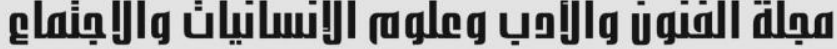

Journal of Arts, Literature, Humanities and Social Sciences www.jalhss.com

29. سر صناعة الاعر اب، لأبي الفتح عثمان بن جني (ت 392هـ)، تحقيق: محمد حسن اسماعيل و أحمد رشدي

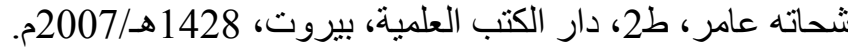

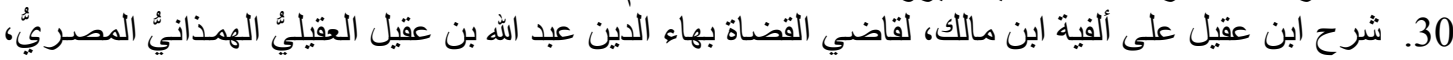

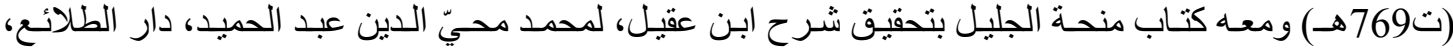

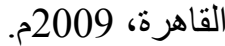
31. شرح التسهيل، لجمال الدين محمد بن عبد الله بن مالك الطائيُّ الجيانيٌ الأندلسيُّ، (ت 672هـ)، تحقيق: محمد

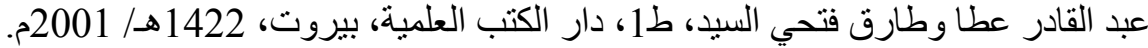

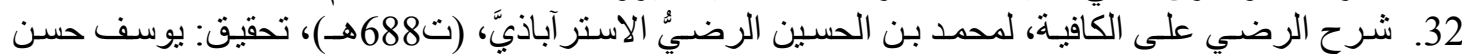

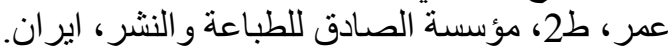

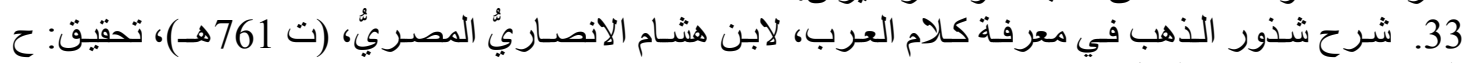

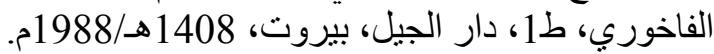

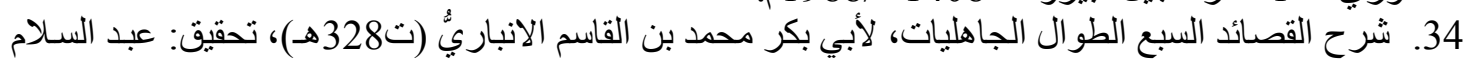

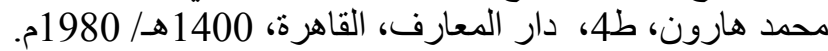

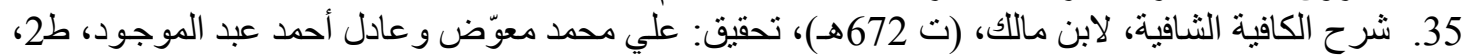

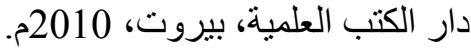

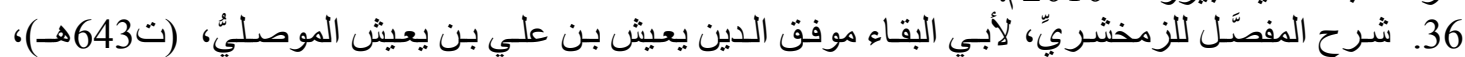

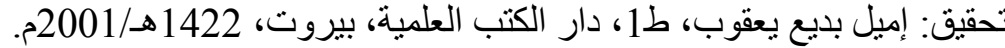

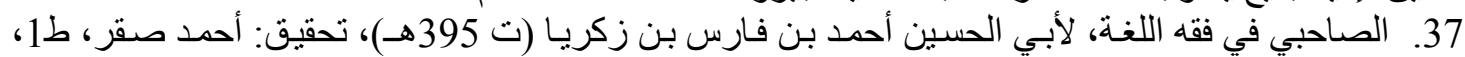

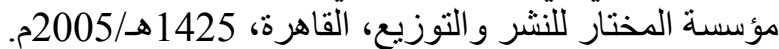

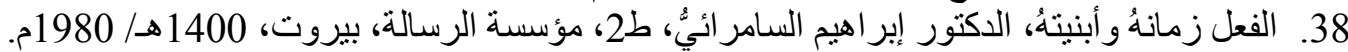

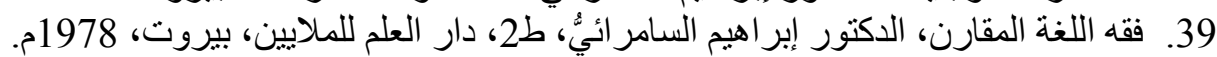

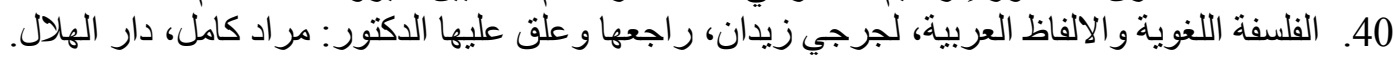
41. في منهج السالك في الكلام على ألفية ابن مالك، لأبي حيّان الاندلسيُ، (ت نيو هافن، 1947م. 42. في النحو العربـي نقد وتوجيـه، الدكتور مهدي المخزومسيُ، ط1، منشـورات المكتبـة العصـرية، بيروت،

43. الكتاب، لابي بشر عمرو بن عثمان بن قتبر المشهور بسيبويه، (ت180 1883هـ). 1ـ تحقيق وشرح: عبد السلام

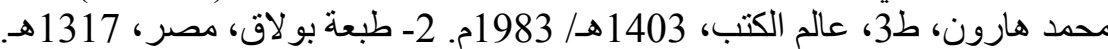

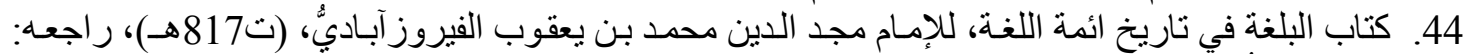

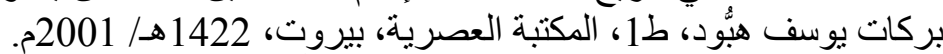

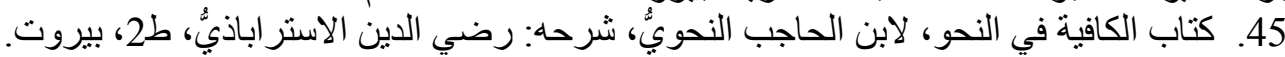

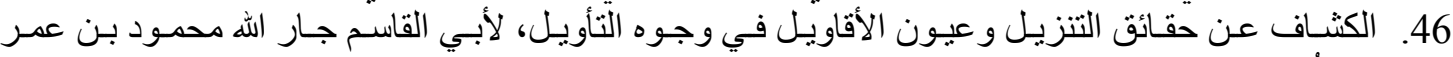

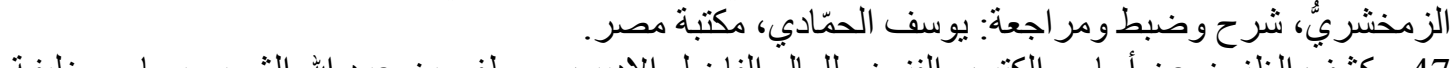

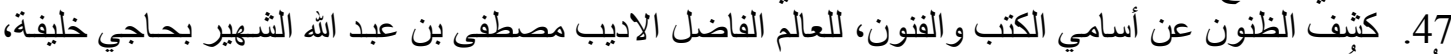

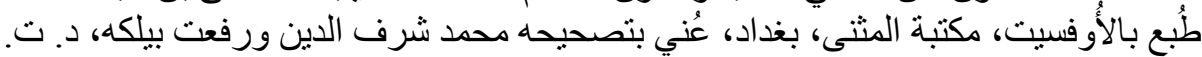

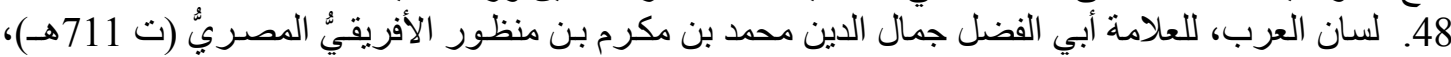

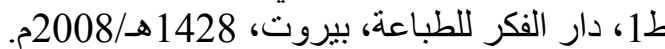
49. اللمع في العربية، لأبي الفتح عُثمان بن جني، (ت 3952هـ)، تحقيق: حامد المؤمن، ط2، عالم الكتب، بيروت،

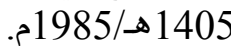

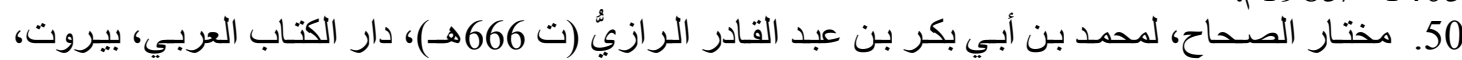

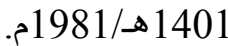

51. مر اتب النحويين، لعبد الواحد بن علي الطيب اللغويڤّ، تحقيق: محمد أبو الفضـل إبر اهيم، ط1، المكتبـة

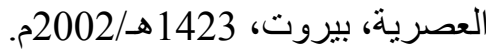




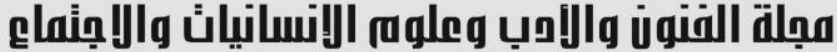

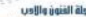

Journal of Arts, Literature, Humanities and Social Sciences www.jalhss.com

52. معاني الحروف، لابي الحسن علي بن عبسى الرمانيٌ النحويٌٌ (ت 384هـ)، تحقيق: د. عبد الفتاح اسماعيل

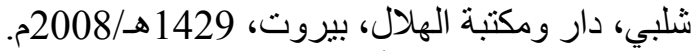

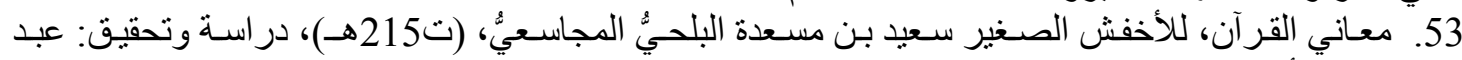

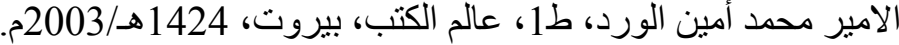

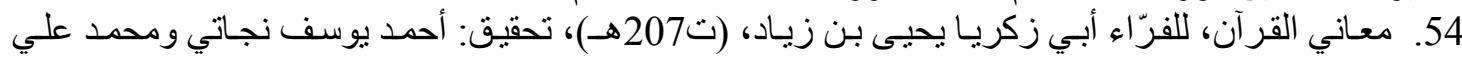

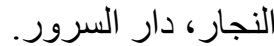

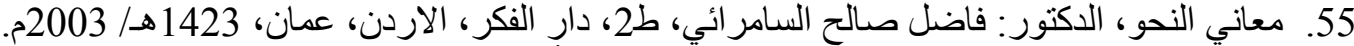

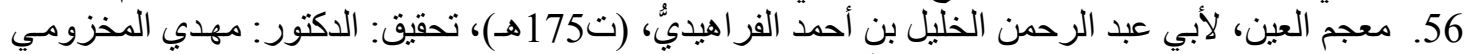

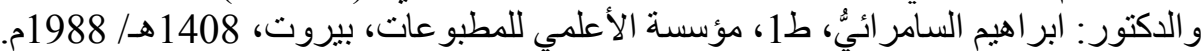

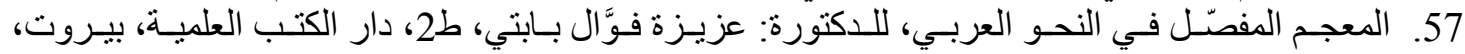

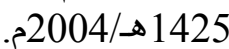

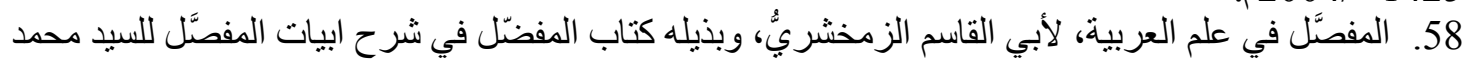

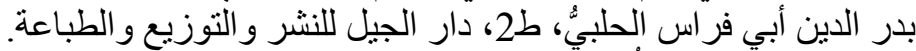

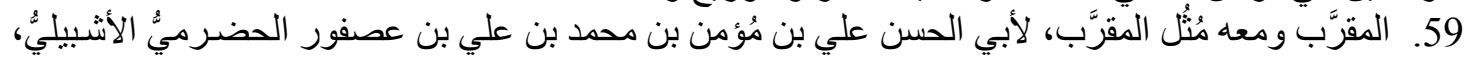

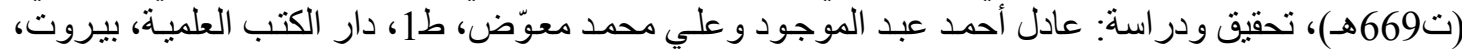

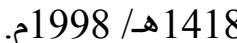

60. مُغني اللبيب عن كتب الأعاريب، لأنب هثام، (ت761 هـ)، تحقيق: محمد محيّ الدين عبد الحميد، دار إحياء

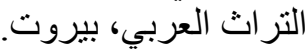
61. من تأريخ النحو، لسعيد الأفغانيُ، دار الفكر.

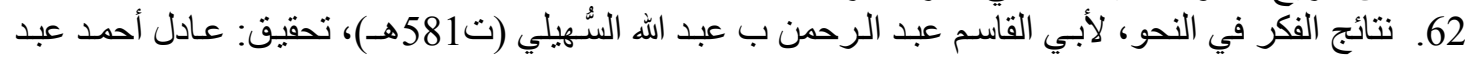

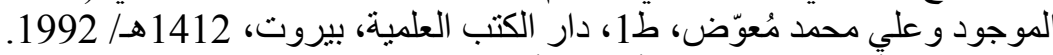

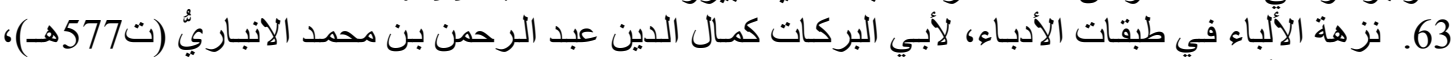

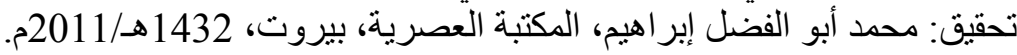

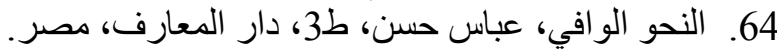

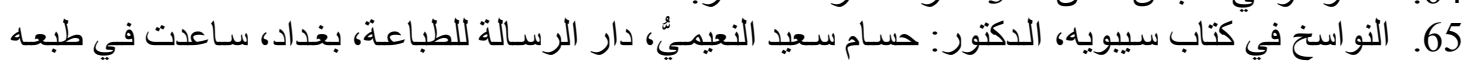

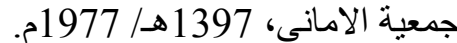

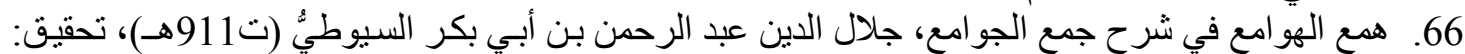

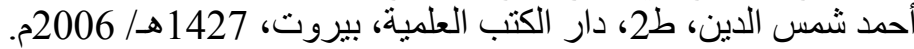

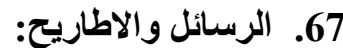

68. المركبـات في العربيـة، خديجـة زبـار عنيزان الحمدانئ، رسـالة ماجستير، كليـة التربيـة، أبن رشـد، جامعـة

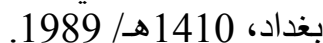




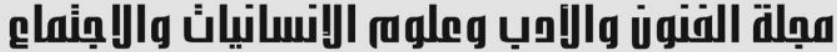

Journal of Arts, Literature, Humanities and Social Sciences www.jalhss.com

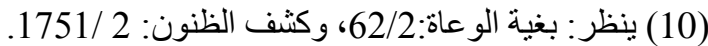

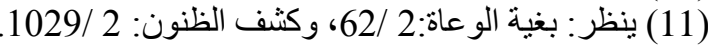

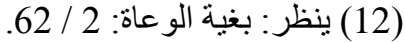
(13) - ينظر : المصدر نفسهاه.

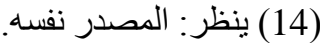
(15) (15) ينظر : المصدر نفسـه. (16) - (16) ينظر : المصدر نفسهاه. (17) - (17) ينظر : المصدر نفسها.

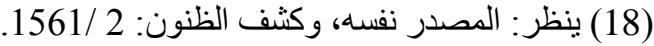

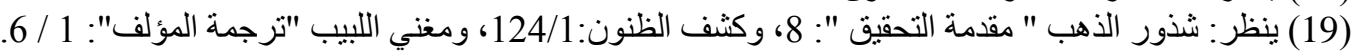

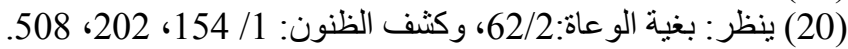

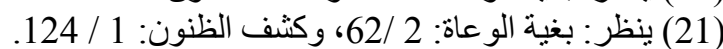

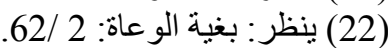

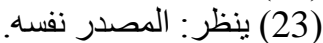

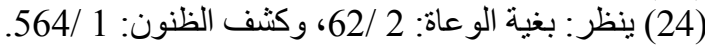

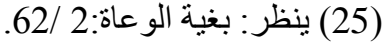

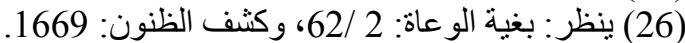

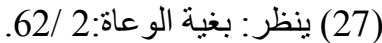

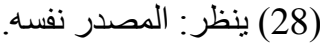

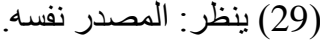

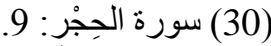

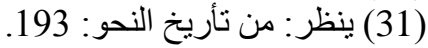

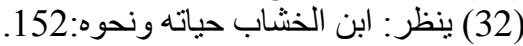

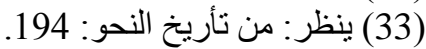

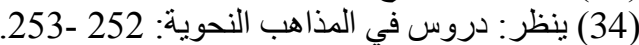

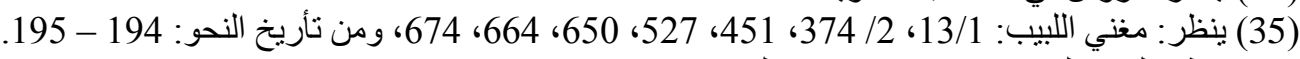

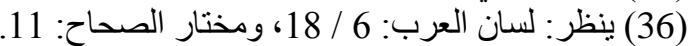

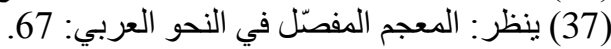
(38) (37) الكتاب: 1 / 12 (3)

(39) ينظر : المصدر نفسه: 3 /496.

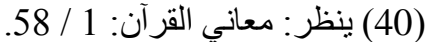
(41) سورة الكهف: 6.

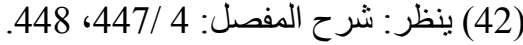
(43) مغني اللبيب:1 / 13 / 13 (42)

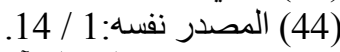

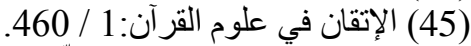
(46) ينظر: الكتاب:2 / 156، 156، و اللّمع في العربية:208، وشرح المفصل:3 / 165، و الجنى الداني:261، ومغني اللبيب: 1 / (47) ينظر : شرح التسهيل: 331 331، وشرح ابن عقيل:4 / 60، و همع الهو امع:2 /501.

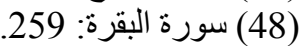
(49) ينظر : شرح الففصل:165 - 167 167، و الجنى الداني: 261، وهمع الهو امع:2 /501.

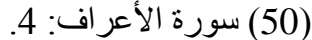

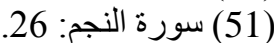

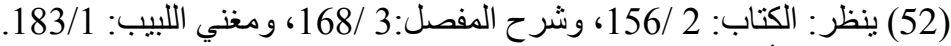




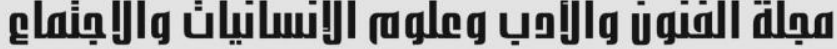

Journal of Arts, Literature, Humanities and Social Sciences

www.jalhss.com

(56) ينظر : التبين عن مذاهب النحويين: 423 - 425. (57) ينظر : الجنى الداني: 261 : 261.

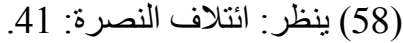

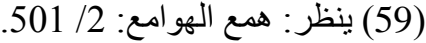

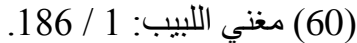

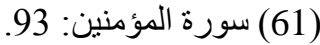

(62) الإنصاف 1 /243، وينظر : معاني القرآن، للفر اءع:1 / 1 / 466.

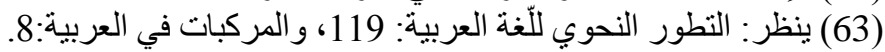

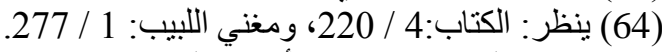

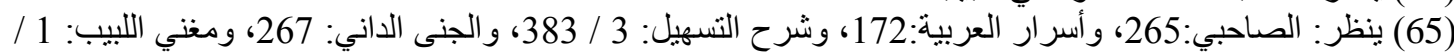

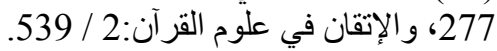

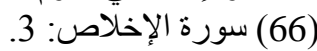

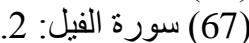

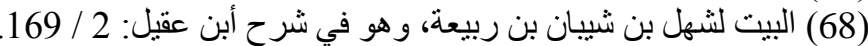

(69) البيت قائله مجهول، وهو في شرح التنهيل:1 /33، و الجنى الداني:266، ومغني اللبيب:1 /277، وشرح الرضي

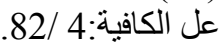

(70) ينظر : شرح التسهيل:12/ /33، و الجنى الداني:266، 266، ومغني اللبيب:

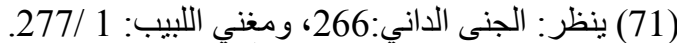

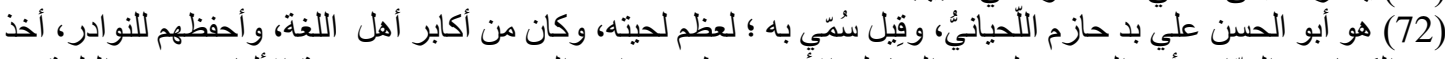

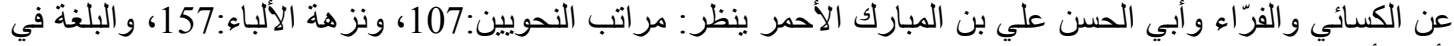

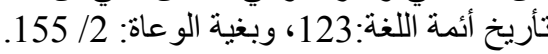

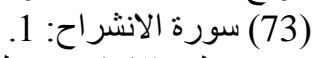
(74) ينظر : الإتقان في علوم القرآن: 2 / 220 / 539.

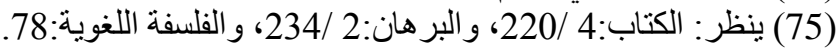

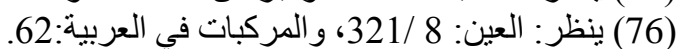

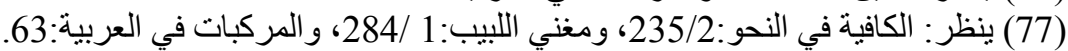

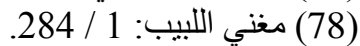

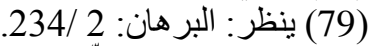

(80) التطور النحوي للّغة العربية:119، وينظر : النية في النحو العربي نقد وتوجيه:255. (81) في النحو العربي نقد وتوجيه: 255.

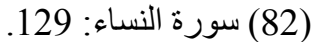

(83) ينظر : المفصّل في علم العربية:307، و الكثاف: 2 /38 /198، ومغني اللبيب:1 /284، وشرح الرضي على الكافية:4 /

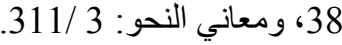

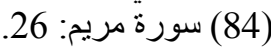

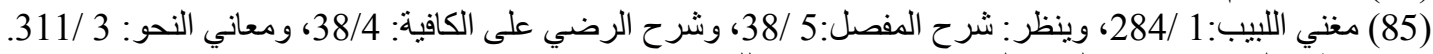

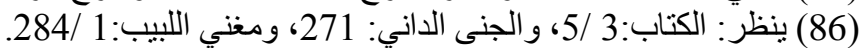

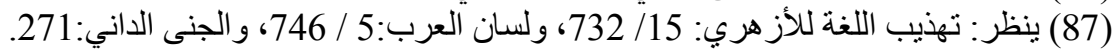

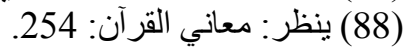

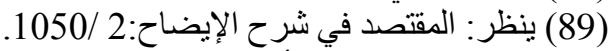

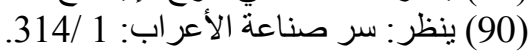

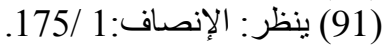

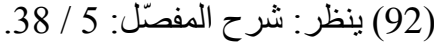

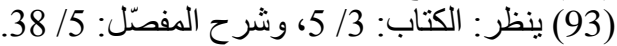

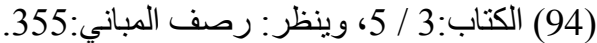

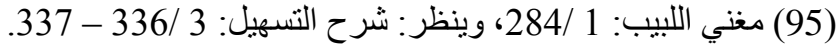

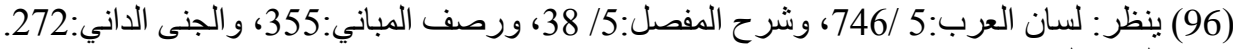

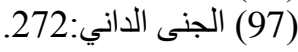




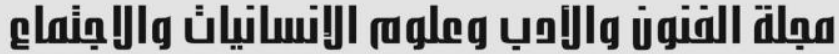

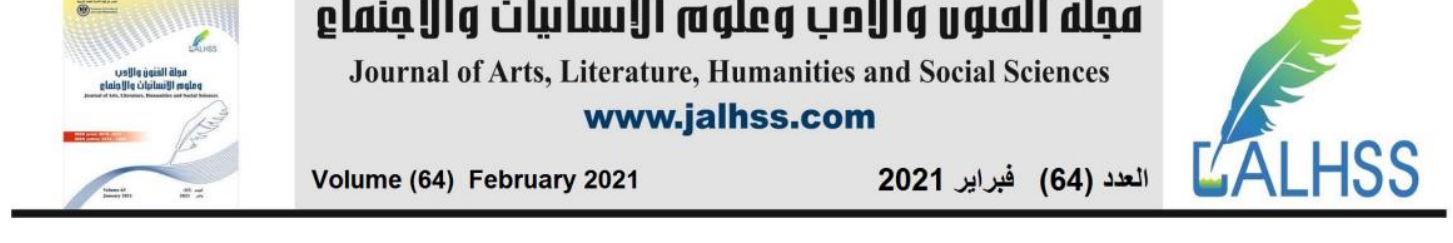

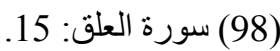

(99) سورة يوسف:32.

(100) مغني اللبيب:101 / 1 /284.

(101) ينظر: رصف المباني: 356،356، 355، 357 (105).

(102) في النحو العربي نقد وتوجيه: 256 (103.

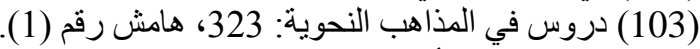

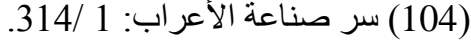

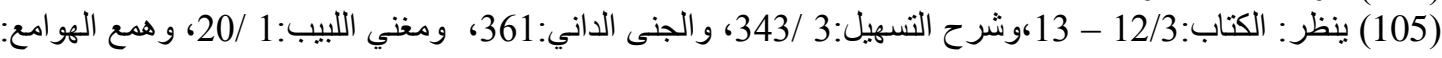
.293/2

(106) ينظر: الكتاب: 4 /2343، ورصف المباني:151، و الجنى الداني:364، ومغني اللبيب: 20/1، وهمع الهوامع:2

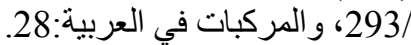

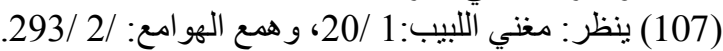

(108) ينظر : المصدرين نفيهيها.

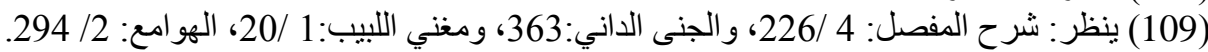

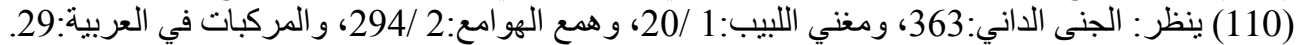

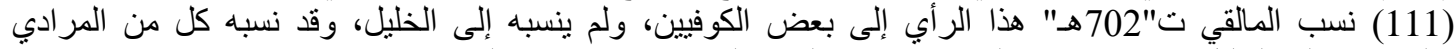

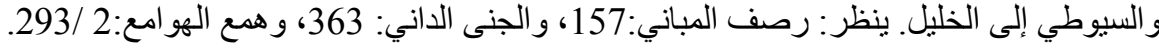
(112) ينظر: الجنى الداني: 363، 363، وهمع الهو امع: 2 / / 295.

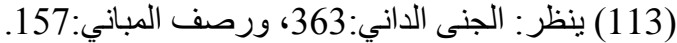

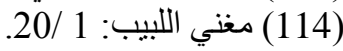
(115) ينظر: رصف المباني: 157 (115)

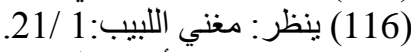

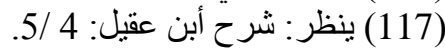

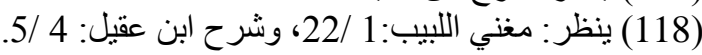

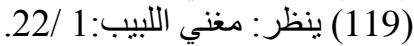

(120) البيت لحسأن بن ثابت، شاعر الرسول محمد(صلى الله عليه وسلم )، وهو في ديو انه:13، وينظر: أوضح المسالك

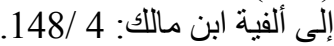

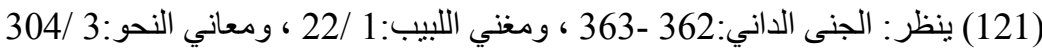

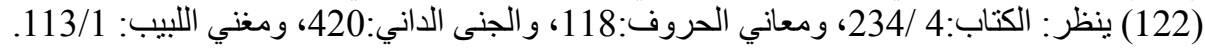
(123) (122) سورة التغابن:7 (122)

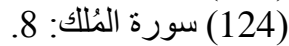

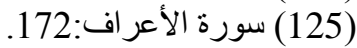
(126) ينظر : معاني القرآن للفرّاء: 1 /52، ومغني اللبيب:1 /113، وهمع الهو امع:491/2). (127) (126) أي الألف المزيدة.

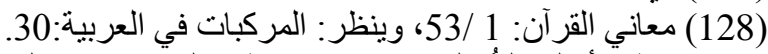

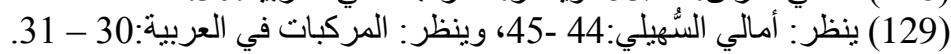

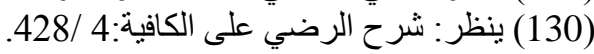

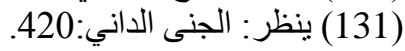

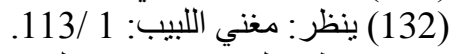

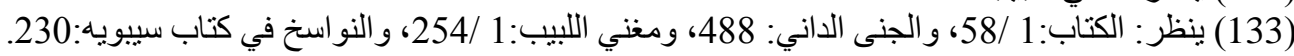

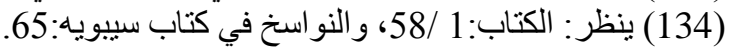

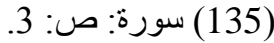

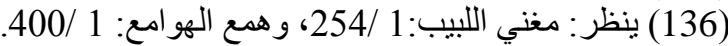

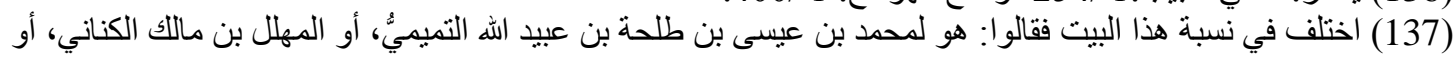

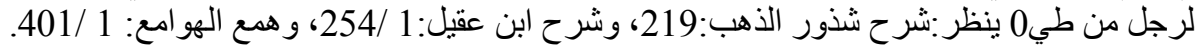

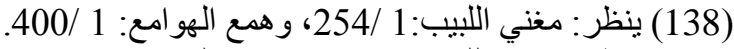
(139) ينظر: مغني اللبيب:1 /254، ولهع الهوامع: 1 / / 402.
} 


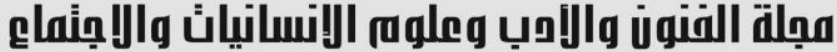

Journal of Arts, Literature, Humanities and Social Sciences www.jalhss.com

(140) ينظر : الجنى الداني:488، ومغني اللبيب:1 /254، وهمع الهو امع:1 /402، و والنواسخ في كتاب سيبو يه:230.

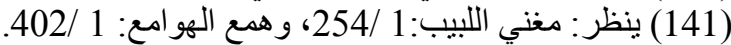

(142) ينظر : المصندرين نفسيهما.

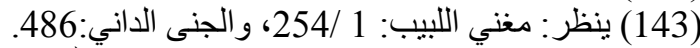

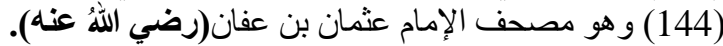

(145) البيت لأبي وجزة السعدي، وهو في تفسير الطبري:124 /1512، ولفظه: العاطِفونَه حين ما مِن عاطفٍ والمُطعِعُونه حين أينِ المطعُ

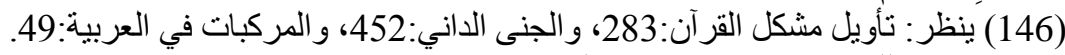

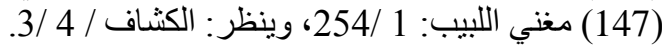

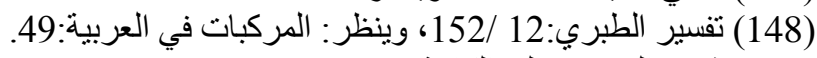
(149) شرح الرضي على الكافية: 2 / 198 (150)

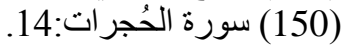

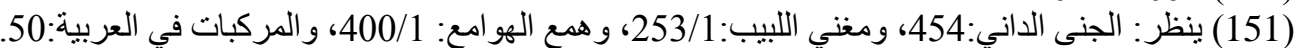

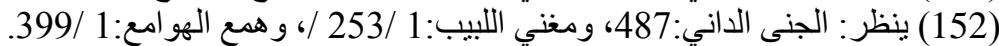

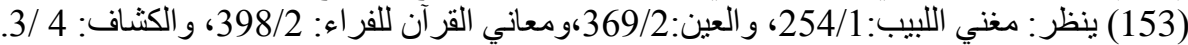

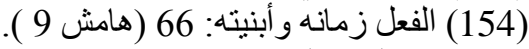
(155) في النحو العربي نقد وتوجيه: 262 (156)

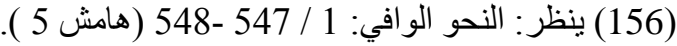
(157) سورة المناققون:4 (156)

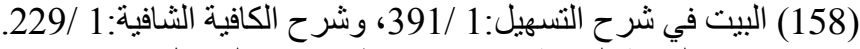

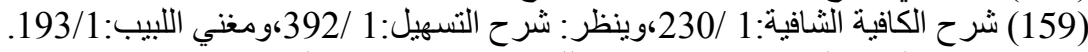

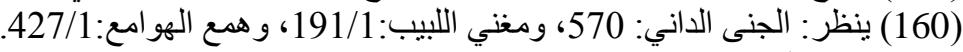
(161) سورة لقمان: 7 (162)

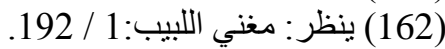

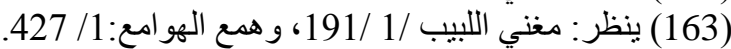

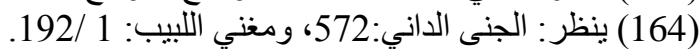
(165) ينظر : مغني اللبيب: 1 / /1962)

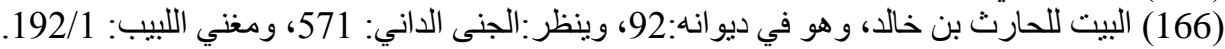

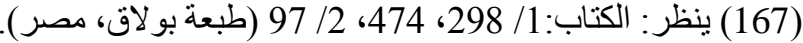
(168) ينظر: الجنى الداني: 568، ومغني اللبيب: 1681/ 1 (161) (169) ينظر: شرح المفصل: 4 / /564.

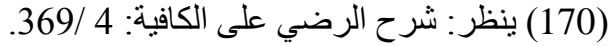

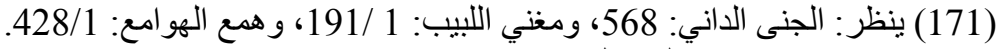

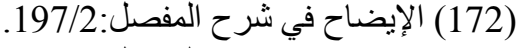

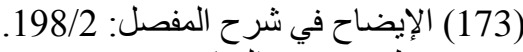

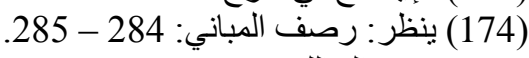

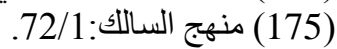

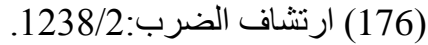

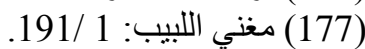
(178) (179) النواسخ في كتاب سيبويه: 245 (17)

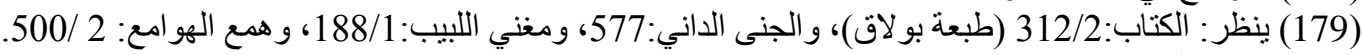

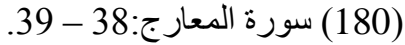

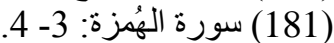

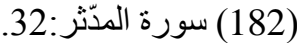

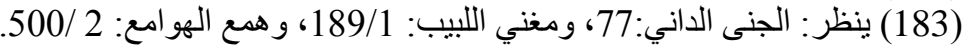
(184) سورة المؤمنون:185) (185) سورة الشعر اء:62. - (184) 


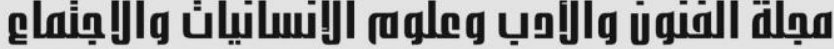

Journal of Arts, Literature, Humanities and Social Sciences www.jalhss.com

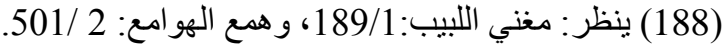

(189) ينظر: الصاحبي:260، و الجنى الداني:578، ورصف المباني:287، ومغني اللبيب: 188/1، وهمع الهوامع: 2 /

(190) ينظر : مغني اللبيب: 188/1) وهمع الهو امع: 2 /500.

(192) هو أبو القاسم الحُسين بن الوليد بن نصر، كان أدئ أديبا نحويا شاعرا، أخذ العربية عن ابن القوطية، توفي سنة (390 هـ

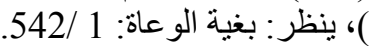

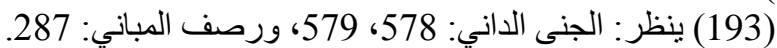

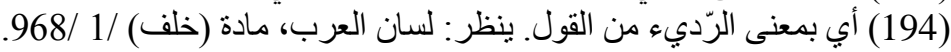

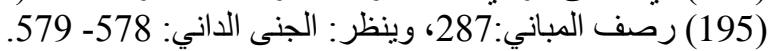

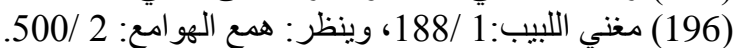

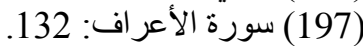

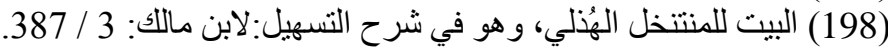
387/ 3 (199) شرح التسهيل

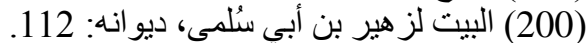

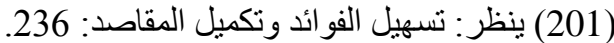

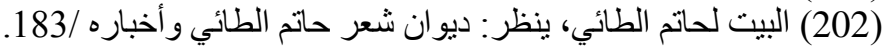

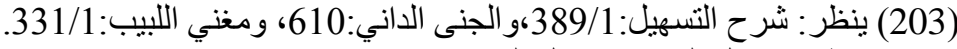
(204) ينظر : تسهيل الفو ائد وتكميل المقاصد:

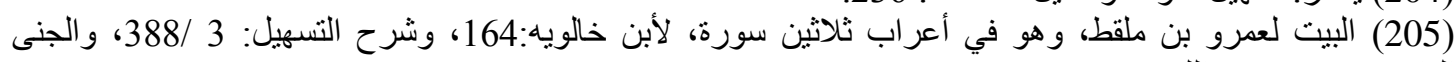
الداني:611، ومغني اللبيب:332/1)

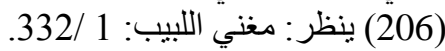

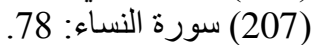

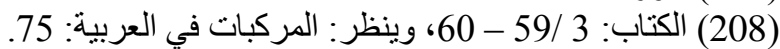

(209) بنظر: شرح القصائد السبع الطو ال، لأبي بكر الانباري:40 الطيات

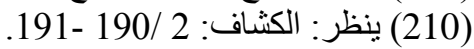

(211) ينظر : شرح الرضي على الكافية: 80/3)

(212) (213) الكتاب: 3 (211)

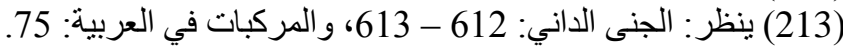

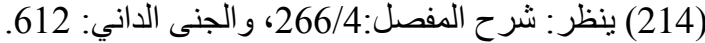

(215) مغني اللبيب: 331 (216)

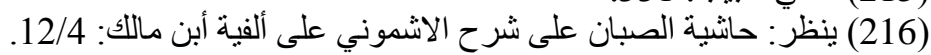

(217) ينظر : المقرّب:391)

(218)

(219)

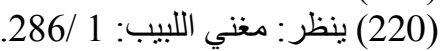

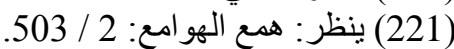

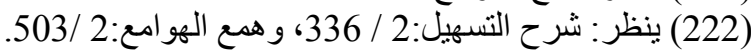

(223) مغني اللبيب: 1 / /224)

(224) ينظر: شرح جمل الزجاجي، لأبن عصفور: 2 /2230، /250، مغني اللبيب:186/1 ، وهمع الهو امع: 2 /503.

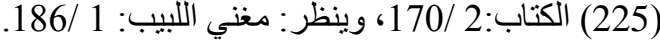

(226) سورة العنكبوت:60)

(227) مغني اللبيب: 1 /1865، وينظر: هور الهنكي: الهو امع: 2 /502 - 503.

(228) سورة يوسف: 105 (لفئ:

(229) ينظر : همع الهو امع: 2 (2283. 


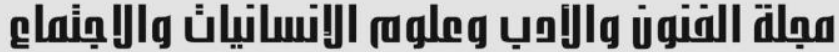

(230) هو أبو الحسن علي بن محمد المعروف بابن خروف الأندلسيُ، كان من أكابر علماء النحو في الأندلس، أخذ النحو

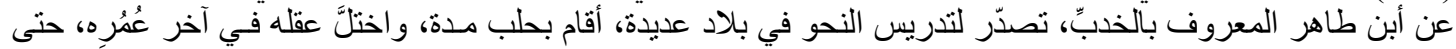

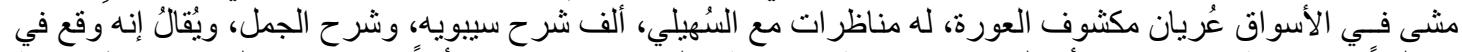

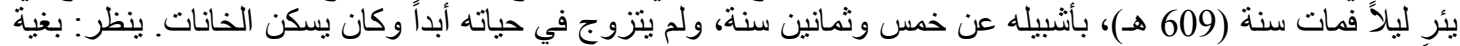

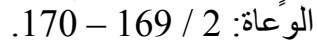

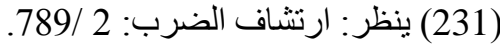

$$
\begin{aligned}
& \text { (232) ارتثاف الضرب:789/2، وينظر : المركبات الضركات في العربية: } 11 .
\end{aligned}
$$

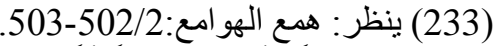

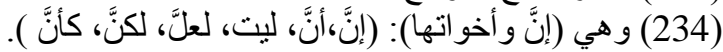

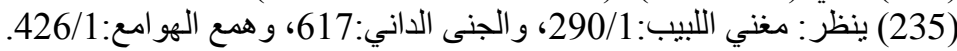

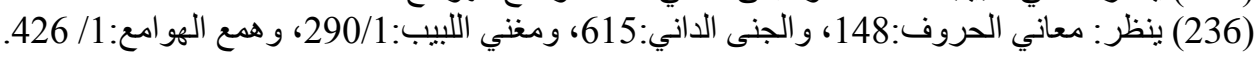

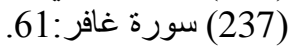

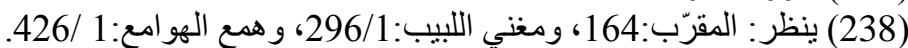

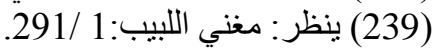

(240) ينظر : الجنى الداني:617، ومغني اللبيب:165/291/ /291، وهمع الهوامع: 1 /426.

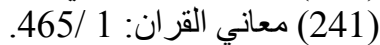

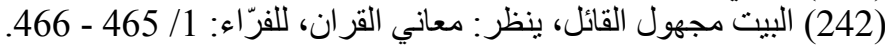

(243) ينظر: الجنى الداني: 617، ومغني اللبيب:291/1، لالفران، وهمع الهو امع: 426/1.

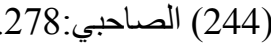

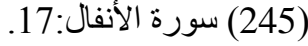

(246) (24) (24) الصاحبي:278)

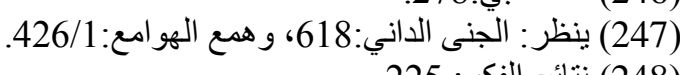

225 (248) ن نتائج الفكر:

(249) شرح المفصل: 4 / / 4 (258).

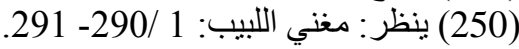

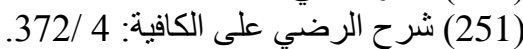

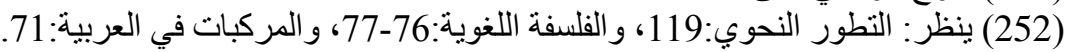

(253) فقه اللغة الدقارن: 252) - 257. 